\title{
Influence of intense scavenging on Pa-Th fractionation in the wake of Kerguelen Island (Southern Ocean)
}

\author{
C. Venchiarutti ${ }^{1,2}$, M. Roy-Barman ${ }^{3}$, R. Freydier ${ }^{4,}{ }^{*}$, P. van Beek ${ }^{2}$, M. Souhaut ${ }^{2}$, and C. Jeandel ${ }^{2}$ \\ ${ }^{1}$ Alfred Wegener Institute, Am Handelshafen 12, 27570 Bremerhaven, Germany \\ ${ }^{2}$ LEGOS (CNRS/UMR 5566), Observatoire Midi-Pyrénées, 14 Avenue Edouard Belin, 31400, Toulouse, France \\ ${ }^{3}$ LSCE/IPSL Laboratoire CNRS/CEA/UVSQ, Domaine du CNRS, Bât 12 - avenue de la Terrasse, \\ 91198 Gif-sur-Yvette Cedex, France \\ ${ }^{4}$ LMTG, Observatoire Midi-Pyrénées, 14 Avenue Edouard Belin, 31400 Toulouse, France \\ *now at: Laboratoire HydroSciences Montpellier, Université Montpellier 2, Place Eugéne Bataillon, 34095 Montpellier, \\ Cedex 5, France
}

Received: 14 April 2011 - Published in Biogeosciences Discuss.: 17 May 2011

Revised: 15 September 2011 - Accepted: 15 October 2011 - Published: 8 November 2011

\begin{abstract}
Dissolved and particulate excess ${ }^{230} \mathrm{Th}$ and ${ }^{231} \mathrm{~Pa}$ concentrations (noted ${ }^{230} \mathrm{Th}_{\mathrm{xs}}$ and ${ }^{231} \mathrm{~Pa}_{\mathrm{xs}}$ respectively) and ${ }^{231} \mathrm{~Pa}_{\mathrm{xs}}{ }^{230} \mathrm{Th}_{\mathrm{xs}}$ activity ratios were investigated on and out of the Kerguelen plateau (Southern Ocean) in the framework of the Kerguelen Ocean and Plateau compared Study project in order to better understand the influence of particle flux and particle chemistry and advection on the scavenging of ${ }^{231} \mathrm{~Pa}$.

In the wake of Kerguelen, particulate ${ }^{231} \mathrm{~Pa}_{\mathrm{xs}}$ is relatively abundant compared to its content in the dissolved phase. This, together with the low fractionation observed between ${ }^{230} \mathrm{Th}$ and ${ }^{231} \mathrm{~Pa}\left(F_{\mathrm{Th} / \mathrm{Pa} \text { ranging from } 0.06 \pm 0.01}\right.$ to $1.6 \pm 0.2)$ reflects the domination of the biogenic silica in the particle pool.

Along the eastern escarpment of the Kerguelen plateau, the strong ${ }^{231} \mathrm{~Pa}_{\mathrm{xs}}$ horizontal gradient in the deep waters highlights the intense removal of ${ }^{231} \mathrm{~Pa}$ at depth, as already observed for ${ }^{230} \mathrm{Th}_{\mathrm{xs}}$. This local boundary scavenging was attributed to re-suspension of opal-rich particles by nepheloid layers, resulting in fractionation factors $F_{\mathrm{Th} / \mathrm{Pa}} \leq 1$ along the Kerguelen plateau slope. Therefore, both the composition (biogenic opal) and the flux (intense along the margin) of particles control the scavenging of the two radionuclides in the Kerguelen wake.

The modelling of ${ }^{231} \mathrm{~Pa}$ distribution with an advectionscavenging model demonstrates that lateral advection of open ocean water on the Kerguelen plateau could supply
\end{abstract}

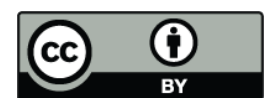

Correspondence to: C. Venchiarutti (cvenchiarutti@gmail.com) most of the ${ }^{231} \mathrm{~Pa}$, which is then efficiently scavenged on the highly productive plateau, as previously proposed for ${ }^{230} \mathrm{Th}_{\mathrm{xs}}$. It stresses that lateral advection can play a significant role in the overall budget of particle reactive trace elements in a coastal-open ocean system.

\section{Introduction}

The Kerguelen plateau (South Indian Ocean) is an ideal laboratory to study the mechanisms of natural iron fertilization in the Ocean. Better defining these mechanisms was the main aim of the KErguelen Ocean and Plateau compared Study project (KEOPS, Blain et al., 2007). For this purpose, a good understanding of the particle dynamics and advection processes in this area was required.

${ }^{231} \mathrm{~Pa}$ and ${ }^{230} \mathrm{Th}$ are natural radionuclides, uniformly produced in seawater by the decay of the homogeneously distributed uranium isotopes $\left({ }^{235} \mathrm{U}\right.$ and ${ }^{234} \mathrm{U}$ respectively). Consequently, they are both produced at a fixed known rate in the ocean with a production activity ratio ${ }^{231} \mathrm{~Pa} /{ }^{230} \mathrm{Th}$ of 0.093. Both radionuclides are particle reactive and therefore rapidly adsorbed onto settling particles and removed (scavenged) from the water column to the sediment. However, their affinity for particles differs, ${ }^{230} \mathrm{Th}$ adsorption coefficients being generally 10 times higher than ${ }^{231} \mathrm{~Pa}$ coefficients (Anderson et al., 1983a; Moran et al., 2002; Chase et al., 2003). Consequently, ${ }^{231} \mathrm{~Pa}$ has a residence time in the water column of 50-200 yr, longer than the 10-40 yr residence time of ${ }^{230} \mathrm{Th}$ (Anderson et al, 1983a; Nozaki et al., 1985;

Published by Copernicus Publications on behalf of the European Geosciences Union. 
Walter et al., 1997), so that these two radionuclides are fractionated in seawater compared to the production ratio. ${ }^{231} \mathrm{~Pa}$ is transported to areas of high particle fluxes (e.g. margins) prior to being scavenged. In contrast, ${ }^{230} \mathrm{Th}$ is mainly scavenged on its production site (Walter et al., 1997; Yu et al., 2001). This enhanced scavenging at ocean margins is named "boundary scavenging" (Spencer et al., 1981; Anderson et al., 1990). Boundary scavenging is the result of the combination of (i) an increasing particle flux (particle flux effect) from the open ocean to the margin and possibly from a change in particulate matter composition (particle composition effect) and (ii) a sufficiently long scavenging residence time of the element (e.g. $\left.{ }^{210} \mathrm{~Pb},{ }^{231} \mathrm{~Pa} . ..\right)$ in the open ocean so that it can be transported from the open ocean where it is produced, to the ocean margins where it is efficiently scavenged.

As for ${ }^{230} \mathrm{Th}$, the oceanic ${ }^{231} \mathrm{~Pa}$ chemical behaviour is considered to be governed by reversible scavenging on settling particles (Bacon and Anderson, 1982). Therefore, in absence of lateral transport of these radionuclides by currents, reversible scavenging yields linear increases with depth of total (dissolved + particulate) ${ }^{231} \mathrm{~Pa}$ and ${ }^{230} \mathrm{Th}$ concentrations below the euphotic layer and at least down to $1000 \mathrm{~m}$ depth (Nozaki et al., 1985; Roy-Barman et al., 1996; Choi et al., 2001; Marchal et al., 2007). Deeper in the water column, deviations from this linearity are often observed. This depletion can be due to either (i) depleted surface waters that are sinking and mixing with deep waters (Rutgers van der Loeff and Berger, 1993; Vogler et al., 1998; Moran et al., 2002; Coppola et al., 2006) or (ii) advection of waters depleted in radionuclides coming from the ocean margins, leading to low radionuclide concentrations in the water column (Venchiarutti et al., 2008; Roy-Barman, 2009).

Both radionuclides are therefore not only used as tracers for particle scavenging (Nozaki et al., 1981; Bacon and Anderson, 1982; Luo and $\mathrm{Ku}$, 2004) but also for the deep ocean circulation or ventilation (Rutgers van der Loeff and Berger, 1993; Scholten et al., 1995; Moran et al., 1997). However, data on the distributions of ${ }^{231} \mathrm{~Pa}$ and ${ }^{230} \mathrm{Th}$ in seawater and particles are still scarce, precluding a full understanding on these radionuclides oceanic behaviour.

For instance, the role of particle composition on the radionuclides scavenging remains unclear. Indeed, ${ }^{231} \mathrm{~Pa}$ appears to be more reactive with inorganic particles $\left(\mathrm{Fe}_{2} \mathrm{O}_{3}\right.$, $\mathrm{MnO}_{2}$ ) or biogenic silica (opal) in carbonate-depleted areas, like in the Southern Ocean (Guo et al., 2002; Chase et al., 2002 and 2004; Scholten et al., 2005). Consequently, in presence of particles rich in $\mathrm{Fe}_{2} \mathrm{O}_{3}, \mathrm{MnO}_{2}$ or biogenic silica, both ${ }^{230} \mathrm{Th}$ and ${ }^{231} \mathrm{~Pa}$ would be adsorbed onto the particles with almost the same efficiency, thereby yielding almost no fractionation between ${ }^{231} \mathrm{~Pa}$ and ${ }^{230} \mathrm{Th}$ (Walter et al., 1999; Chase et al., 2002). However, questions still remain concerning the exact affinity of these radionuclides according to particle type, grain size and whether they are adsorbed or rather incorporated in the particles.
Moreover, recent debates question the relevance of ${ }^{231} \mathrm{~Pa} /{ }^{230} \mathrm{Th}$ ratio as a circulation tracer. Indeed, it appears that the ${ }^{231} \mathrm{~Pa} /{ }^{230} \mathrm{Th}$ could reflect the influence of the surrounding biological productivity (in particular diatoms) rather than the circulation imprint (Bradtmiller et al., 2006, 2009; Hayes et al., 2011), and questions still remain concerning the effect of ocean margins on the ${ }^{231} \mathrm{~Pa} /{ }^{230} \mathrm{Th}$.

Here, we present the ${ }^{231} \mathrm{~Pa}$ distributions in both solid and dissolved phases as well as the ${ }^{231} \mathrm{~Pa} /{ }^{230} \mathrm{Th}$ fractionation in the Kerguelen area during the KEOPS program. A salient feature of this area is the biogeochemical contrast between the Kerguelen plateau and the open-ocean (phytoplankton bloom versus High Nutrient Low Chlorophyll -HNLC- area). This study complements the work on ${ }^{230} \mathrm{Th}$ during KEOPS (Venchiarutti et al., 2008) which pointed out that:

- Using the "classical" 1-D scavenging model does not allow obtaining realistic ${ }^{230} \mathrm{Th}$ scavenging rates over the Kerguelen plateau. Realistic scavenging rates were obtained by using a new advection-scavenging model that takes into account both ${ }^{230} \mathrm{Th}$ scavenging and advection of HNLC open-ocean waters over the productive plateau.

- Using this model, Venchiarutti et al. (2008) demonstrated that scavenging is strongly enhanced on the plateau and along its eastern flank (mean settling speed of small particles one order of magnitude larger than in the open ocean) and that, despite this strong increase of scavenging compared to the open ocean, the ${ }^{230} \mathrm{Th}$ concentration does not drop down to zero because the continuous inflow of open ocean water brings new ${ }^{230} \mathrm{Th}$ on to the plateau. It suggests that advection of waters from the open ocean could bring other trace elements as well and impact on the budget of these elements over the plateau.

- Enhanced scavenging of ${ }^{230} \mathrm{Th}$ on the plateau and along its eastern flank was tentatively attributed to the occurrence of particle re-suspension by nepheloid layers.

Venchiarutti et al. (2008) also showed that the Kerguelen plateau represents an ideal "simple" case to study boundary scavenging because there is a high gradient of particle flux over a limited distance linked to a well constrained circulation over the plateau. As mentioned earlier, ${ }^{231} \mathrm{~Pa}$ is more prone to boundary scavenging than ${ }^{230} \mathrm{Th}$. Consequently, a significant boundary scavenging of ${ }^{231} \mathrm{~Pa}$ is expected over the Kerguelen plateau.

Analysing ${ }^{231} \mathrm{~Pa}$ in this area should also bring constraints on $\mathrm{Pa} / \mathrm{Th}$ fractionation during scavenging processes. In particular, precise budgeting of the advection and scavenging flux using the Kerguelen boundary scavenging model should allow elucidation of the respective influence of the particle flux versus chemistry effects, a question still in debate. 


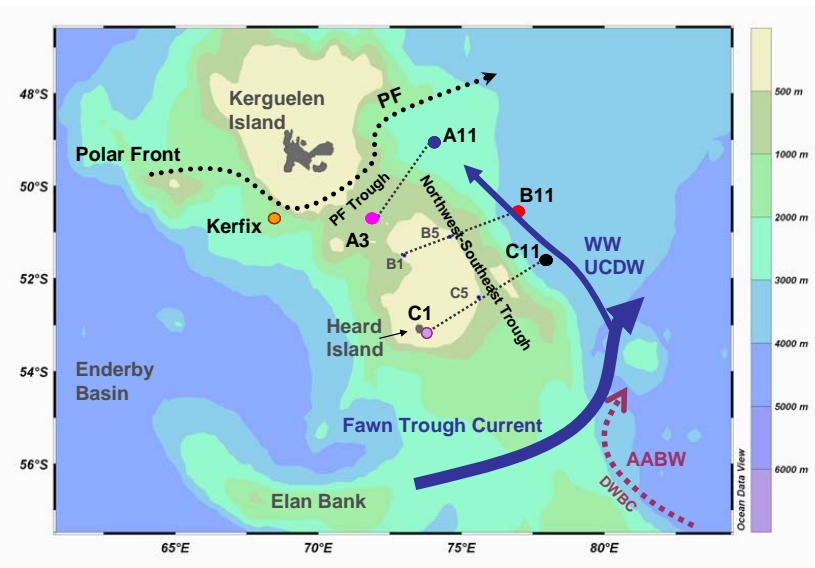

Fig. 1. Sample location and major hydrographical features during KEOPS (inspired from Park et al., 2008). The 6 stations (out of 9) analysed for $\mathrm{Pa}$ (dissolved and particulate) are highlighted on the map. Blue arrow: Fawn Trough Current $\left(38 \mathrm{~Sv}=38 \times 10^{6} \mathrm{~m}^{3} \mathrm{~s}^{-1}\right)$ and its northward branch along the eastern escarpment of the Kerguelen plateau, carrying Winter Water (WW) and Circumpolar Deep Water (Upper and Lower CDW). Dotted purple arrow: Antarctic Bottom Waters (AABW) coming via the Deep Western Boundary Current from the Adelie Land. This figure was realised using Ocean Data View (R. Schlitzer, http://odv.awi.de, 2011).

Thus, the first aim of the present study is to determine if the intense scavenging highlighted by ${ }^{230} \mathrm{Th}$ on the Kerguelen plateau and along the eastern slope (Venchiarutti et al., 2008) also affects ${ }^{231} \mathrm{~Pa}$ distribution. If the model proposed for ${ }^{230} \mathrm{Th}$ does not account correctly for ${ }^{231} \mathrm{~Pa}$, it would indicate the occurrence of processes allowing the decoupling of the two elements. The other aim is to determine the role of particle composition vs. particle flux on the sedimentary $\mathrm{Pa} / \mathrm{Th}$ ratios. Hence, we propose to study the fractionation of these two radionuclides over and out of the Kerguelen plateau, based on ${ }^{231} \mathrm{~Pa}$ partition coefficients $\left(\mathrm{K}_{\mathrm{Pa}}\right)$ and the ${ }^{231} \mathrm{~Pa} /{ }^{230} \mathrm{Th}$ fractionation factor $\left(F_{\mathrm{Th} / \mathrm{Pa}}\right)$.

\section{Sampling and analytical methods}

\subsection{Regional settings: hydrography}

The Southern Ocean is the largest HNLC area in the world Ocean (Sarmiento et al., 1998; Tréguer and Pondaven, 2002; Marinov et al., 2006). However, most of the islands of this ocean experience intense summer phytoplankton blooms (Pollard, 2009; Frew et al., 2006). In the case of the Kerguelen Island and plateau zone, a large bloom extends yearly South of the Polar Front (PF, Fig. 1) over the Kerguelen plateau, to which it is restrained by the bathymetry and surrounding HNLC waters (Blain et al., 2007; Mongin et al., 2008).
The Kerguelen plateau divides the Antarctic Circumpolar Current (ACC) into a northern flow, north of the Kerguelen Island and a southern flow, through the Fawn Trough, delimiting the so called "central Kerguelen plateau" (Park et al., 2008; Mongin et al., 2008). This latter extends therefore from the Kerguelen Island (north of the PF) to the Heard/McDonald Islands, its southern limit (Fig. 1). It is shallower than $\sim 560 \mathrm{~m}$, with some shallow seamounts and is delimited by deeper troughs and ridges (Park et al., 2008; Mongin et al., 2008): at north, the PF Trough $(\sim 650 \mathrm{~m})$ and south, the Fawn Trough $(\sim 2650 \mathrm{~m})$ and along the southeastern part of the plateau, the Northwest-Southeast Trough ( 600 m).

LADCP measurements (Park et al., 2008) highlighted the contrast between the weak geostrophic circulation of the shallow plateau, with a general northward flow $\leq 5 \mathrm{~cm} \mathrm{~s}^{-1}$ and the circulation along the eastern flank of the plateau, where a strong north-westward branch $\left(\sim 18 \mathrm{~cm} \mathrm{~s}^{-1}\right)$ of the Fawn Trough Current (FTC) brings cold Antarctic waters, likely originating from south of the Elan Bank and the eastern Enderby Basin (Fig. 1). These waters include Winter Water (WW), Upper and Lower Circumpolar Deep Waters (UCDW and LCDW respectively). When exiting the FTC, these waters are encountering cold Antarctic waters within the northernmost extent of the Deep Western Boundary Current (DWBC) flowing along the eastern escarpment plateau from the Australian- Antarctic Basin (McCartney and Donohue, 2007; Roquet et al., 2009).

During the KEOPS cruise in the Austral summer 2005, three transects were covered on and out of the central Kerguelen plateau, stations numbered from 1 to 7 and 8 to 11 respectively (Fig. 1). Station A3 was located in the core of the large bloom on the central plateau and station $\mathrm{C} 1$ was at the southern extent of this central plateau, whereas the offplateau stations Kerfix, A11, B11 and C11 were considered as open-ocean stations in HNLC waters (Fig. 1). The bloom was mostly dominated by large diatoms in surface waters, and sediments on the plateau were dominated by siliceous ooze (Armand et al., 2008). The export of particulate carbon on the Kerguelen plateau was found to be almost double that in the surrounding HNLC waters (Savoye et al., 2008). Bacterial activity in the upper $125 \mathrm{~m}$ depth of the plateau was higher than in the HNLC area whereas the inverse was observed for the mesopelagic layer (Obernosterer et al., 2008; Jacquet et al., 2008). This difference was attributed to the occurrence of larger diatoms cell sizes on the plateau than in the HNLC waters.

Finally, Zhang et al. (2008), van Beek et al. (2008) and Chever et al. (2010) demonstrated that waters originating from further south of the Kerguelen plateau and spreading northward over the plateau, were likely enriched in trace elements due to shelf weathering in the vicinity of Heard Island. These advected waters may be an important source of trace elements to the Kerguelen plateau and contribute significantly to the natural fertilisation. 


\subsection{Sampling}

The sampling and preparation procedures - common for both radionuclides - are fully detailed in Venchiarutti et al. (2008). Below, we will summarize only briefly some specific treatments related to the $\mathrm{Pa}$ analysis.

Seawater samples were collected during KEOPS cruise on board the R/V Marion Dufresne (19/01/05-13/02/05, Fig. 1) using General Oceanics 12 L-Niskin bottles and a Seabird SBE19 + CTD. The analysis of the dissolved ${ }^{231} \mathrm{~Pa}$ was performed at 4 out of the 9 stations sampled during KEOPS: on (A3 and C1) and off (B11 and C11) the Kerguelen plateau. The core of the bloom (station A3) was sampled twice, 12 days apart, for the radionuclide analysis (referred as A3-33 for the first visit and A3-77 for the second).

Briefly, the 301-seawater samples were first filtered through $47 \mathrm{~mm}$ diameter Millipore filters $(0.65 \mu \mathrm{m}$ Durapore or $0.8 \mu \mathrm{m}$ Versapore), spiked with the corresponding yield tracers, $50 \mathrm{pg}$ of ${ }^{229} \mathrm{Th}$ and ca. $140 \mathrm{fg}$ of ${ }^{233} \mathrm{~Pa}$ (produced by neutron activation of ${ }^{232} \mathrm{Th}$ ). After $12 \mathrm{~h}$ equilibration, both radionuclides were co-precipitated, with $\mathrm{KMnO}_{4}$ and $\mathrm{MnCl}_{2}$ solutions, by addition of $\mathrm{NH}_{4} \mathrm{OH}$, based on the protocol of Rutgers van der Loeff and Moore (1999). After $24 \mathrm{~h}$ homogenisation, the samples were filtered through $142 \mathrm{~mm}$ diameter Millipore membranes and the filters stored in Petridishes.

Particulate ${ }^{231} \mathrm{~Pa}$ was collected using in situ pumps (McLane and Challenger Oceanic systems) and analyzed at 4 stations: A3-77, A11, C11 and Kerfix. At each station, 83-25641 were filtered in situ through $0.65 \mu \mathrm{m}$ Durapore or $0.8 \mu \mathrm{m}$ Versapore filters (diameters of 142 or $293 \mathrm{~mm}$ ) and the filters were folded and stored in Petri-dishes to be analysed once back at the home laboratory.

\subsection{Analytical procedures}

All the analytical procedures were conducted using acidcleaned containers and materials, double-distilled reagents, and the analyses were performed in clean-rooms (Class Iso 5-6) at the home laboratory LEGOS.

\subsubsection{Dissolved samples}

Back at the lab, the Mn-filter coprecipitates were processed for the analysis of dissolved ${ }^{231} \mathrm{~Pa}$. However, due to technical problems, the co-precipitation yield could not be determined except for the samples collected at A3-33, for which non-leached filters were counted for gamma spectrometry at the LSM (Laboratoire Souterrain de Modane, French Alps). The co-precipitation recovery was $103 \pm 11 \%$ for nine A333 samples (Table 1). This good recovery was encouraging and we assumed that the co-precipitation step was as efficient as at A3-33 for all the KEOPS stations.

The Mn-filter precipitates were leached in $9 \mathrm{M} \mathrm{HCL}$ baths. However, because of a 4-month mass spectrometer
Table 1. Chemical and co-precipitation yields for the KEOPS ${ }^{231} \mathrm{~Pa}$ samples.

\begin{tabular}{lcc}
\hline Sample types & Chemical yields $^{\mathrm{a}}$ & $\begin{array}{c}\text { Co-precipitation } \\
\text { yields }\end{array}$ \\
\hline Dissolved $^{231} \mathrm{~Pa}$ & $14-97 \%(57 \pm 4 \%)$ & $103 \pm 11 \%$ \\
$(N=23)$ & $(N=9)$ \\
Particulate $^{231} \mathrm{~Pa}$ & $5-51 \%(24 \pm 5 \%)$ & $\mathrm{X}$ \\
& $(N=13)$ & \\
\hline
\end{tabular}

a Chemical yield ranges (left column) obtained by Isotope Dilution take into account all the chemical steps carried out after spiking the samples with the corresponding yield tracers (i.e after the co-precipitation step for dissolved samples and after leaching for the particles). Average yield values are reported into brackets (see details in Sect. 2.4.3).

${ }^{\mathrm{b}} \mathrm{Pa}$ co-precipitation yields (right column) were estimated with gamma-spectrometry at station A3-33 (see details in Section 2.3.1).

$\mathrm{N}$ represents the number of samples analysed and therefore used for the average values.

breakdown, the analysis of the dissolved ${ }^{231} \mathrm{~Pa}$ concentrations at four stations (A3-77, B11, C11 and C1) was postponed for almost one year and consequently no ${ }^{233} \mathrm{~Pa}$ spike remained at all in these samples. Therefore, the Mn-filter leachates at these four stations were split into two aliquots (each equivalent to 151 seawater). One aliquot was dedicated in the first instance to the Th analysis (Th results are reported in Venchiarutti et al., 2008). The other aliquot was stored in $9 \mathrm{M} \mathrm{HCl}$ and $\mathrm{HF}$ to enable later determination of the ${ }^{231} \mathrm{~Pa}$ concentrations by isotope dilution, after re-spiking with a new ${ }^{233} \mathrm{~Pa}$ spike (prepared by milking a solution of ${ }^{237} \mathrm{~Np}$ at the Alfred Wegener Institute, AWI).

After evaporation of the leaching solution to almost dryness, the samples were spiked with ${ }^{236} \mathrm{U}(\sim 40 \mathrm{pg})$ to trace ${ }^{233} \mathrm{U}$ bleeding in the Pa fraction (Choi et al., 2001). The Pa samples were then purified (from $\mathrm{Th}$ and $\mathrm{U}$ ) using an anion exchange resin (AG1x8, 100-200 mesh). The elution steps are further documented in Venchiarutti et al. (2008) and Jeandel et al. (2011a).

\subsubsection{Particle samples}

The ${ }^{231} \mathrm{~Pa}$ and Th particulate samples were leached in a mixture of concentrated $\mathrm{HCl}$ and $\mathrm{HNO}_{3}$ followed by the addition of Suprapur HF, based on the protocols given in Tachikawa et al. (1997) and Venchiarutti et al. (2008).

As for the dissolved samples, machine breaks led us to split the leachates in order to allow the particle analysis of Th isotopes, performed on $\sim 20 \%$ aliquot of the leachate (Venchiarutti et al., 2008). Concentrations of multiple elements were later determined with ICP-MS (Agilent) on $2 \%$ of the remaining $\sim 80 \%$ of the initial leachates. Ultimately, after spiking with the corresponding yield tracers $\sim 100 \mathrm{fg}$ ${ }^{233} \mathrm{~Pa}$ (AWI batch), $\sim 20 \mathrm{pg}{ }^{229} \mathrm{Th}$ and $15 \mathrm{pg}$ of ${ }^{236} \mathrm{U}$, the particulate $\mathrm{Th}$ and $\mathrm{Pa}$ of the remaining leachates were then 
separated and purified through the same anion exchange resin described in Venchiarutti et al., 2008.

Both sets of particulate Th data, resulting from the analysis of the $\sim 20 \%$ and $\sim 80 \%$ leachate samples gave consistent results (Venchiarutti et al., 2008).

\subsection{Spectrometric analysis}

After the chromatographic separation, both particulate and dissolved ${ }^{231} \mathrm{~Pa}$ purified fractions were measured within $24 \mathrm{~h}$ (so that ${ }^{233} \mathrm{~Pa}$ decay to ${ }^{233} \mathrm{U}$ is minimal, see Sect. 2.4.2) in a $2 \% \mathrm{HNO}_{3}$ solution on a Finnigan Neptune MC-ICPMS (Observatoire Midi-Pyrénées, Toulouse) and their concentrations calculated by isotope dilution from the measured ${ }^{233} \mathrm{~Pa} /{ }^{231} \mathrm{~Pa}$ ratio.

Th isotope measurement is further detailed in Roy-Barman et al. (2005) and Venchiarutti et al. (2008). Pa analysis was performed according to the protocols derived from Choi et al. (2001) and Regelous et al. (2004). Pa samples were introduced into the plasma through a Cetac Aridus system, equipped with a PFA microflow nebulizer (Elemental Sci-

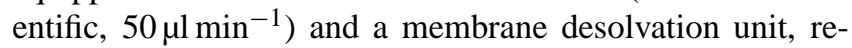
sulting in a passive sample uptake (without peristaltic pump) of $\sim 60 \mu \mathrm{min}^{-1}$. This system was optimized using $\mathrm{N}_{2}$ (flow rate of $5 \mathrm{ml} \mathrm{min}^{-1}$ ) and $\mathrm{Ar}$ (sweep gas, flow rate of $\sim 10 \mathrm{ml} \mathrm{min}^{-1}$ ) gases.

Before each sequence for Pa measurements, the instrument was tuned and peak shapes were improved, for both Faraday cups and SEM, using a standard solution of natural U (SRM $4321 \mathrm{C}$ ), with a certified ${ }^{238} \mathrm{U} /{ }^{235} \mathrm{U}$ ratio of $139.67 \pm 0.016$. This U solution was also run every eight samples in order to bracket the samples and check the instrument short and longterm variability and mass bias (linear correction) during the analysis.

To prevent from any cross-contamination (carry-over) between samples, the system was thoroughly cleaned with a $2 \% \mathrm{HNO}_{3} \mathrm{v} / \mathrm{v}$ solution after each sample run and acid blanks were run prior to each measurement.

\subsubsection{Corrections for ${ }^{232} \mathrm{Th}$ tailing and isobaric interferences}

The importance of ${ }^{232} \mathrm{Th}$ tailing correction for masses 230 and 231 have been previously underlined by Choi et al. (2001); Pichat et al. (2004) and Thomas et al. (2006). However, tailing effect might be attenuated for seawater samples because the ${ }^{232} \mathrm{Th}$ concentration is generally low. Nevertheless, the abundance sensitivity or tailing correction was checked for each of our samples and the counts on mass 231 were corrected using a linear correction based on the systematic measurements of the masses 230.5 and 231.5 for ${ }^{231} \mathrm{~Pa}$ (Choi et al., 2001). The abundance sensitivity of the MC-ICP-MS at the time of the Pa analyses was $\sim 2$ ppm for masses $1 \mathrm{amu}$ apart, i.e. on ${ }^{231} \mathrm{~Pa}$ peak, with the Retarding Potential Quadrupole lens- RPQ settings at this time.
However, thanks to an efficient chromatographic separation, leaving typically less than $2.5 \pm 1.6 \%$ of ${ }^{232} \mathrm{Th}$ in the Pa fraction (Jeandel et al., 2011a), the ${ }^{231} \mathrm{~Pa} /{ }^{232} \mathrm{Th}$ ratio in the $\mathrm{Pa}$ fractions was typically of $\sim 1 \times 10^{-3}$ (except in one sample for which ${ }^{231} \mathrm{~Pa} /{ }^{232} \mathrm{Th}=7 \times 10^{-4}$ ).

Isobaric interferences from hydride formation $\left({ }^{232} \mathrm{Th}^{1} \mathrm{H}\right)$, that can affect ${ }^{233} \mathrm{~Pa}$ measurements, were significantly limited when using the membrane desolvation and low sample uptake of $\sim 60 \mu \mathrm{min}^{-1}$ (Choi et al., 2001; Pichat, 2001; Regelous et al., 2004). We measured the 233/232 ratios for different ${ }^{232} \mathrm{Th}$ concentrations $\left(0.25-5 \mathrm{ng} \mathrm{g}^{-1}\right)$ : values varied from $0.48 \times 10^{-5}$ to $1 \times 10^{-5}$ comparable to the $233 / 232$ ratio of $0.95 \times 10^{-5}$ found by Choi et al. (2001) on a HRICP-MS for a similar range of ${ }^{232} \mathrm{Th}$ concentrations.

For KEOPS samples, most of the ${ }^{232} \mathrm{Th}$ concentrations in seawater (Venchiarutti et al., 2008) were typically lower than $100 \mathrm{pg} \mathrm{kg}^{-1}$ (except for a few samples, notably at $\mathrm{C} 1$ ), so that the highest measurable ${ }^{232} \mathrm{Th}$ and ${ }^{233} \mathrm{~Pa}$ quantities (for a 151 sample) were typically lower than $1.6 \mathrm{ng}\left(0.8 \mathrm{ng} \mathrm{g}^{-1}\right.$ in $2 \mathrm{ml}$ ) and $140 \mathrm{fg}$ respectively. Moreover, the efficient column separation of $\mathrm{Th}$ and $\mathrm{Pa}$ allows us to limit the percentage of ${ }^{232}$ Th "bleeding" $(<2.5 \%)$ in the Pa fraction, thereby inducing a ${ }^{233} \mathrm{~Pa} /{ }^{232} \mathrm{Th}$ ratio $<3.73 \times 10^{-3}$ in the samples. Consequently, taking the highest ${ }^{232} \mathrm{Th}^{1} \mathrm{H} /{ }^{232} \mathrm{Th}$ ratio $=1 \times 10^{-5}$ yields to a hydride correction typically $<0.3 \%$.

\subsubsection{Corrections for uranium bleeding and in-growth}

Adding ${ }^{236} \mathrm{U}$ to the seawater and particulate samples prior to the anion exchange column allowed us to monitor the efficiency of the column separation of $\mathrm{U}$ and $\mathrm{Pa}$, and thus to ensure that the $\mathrm{Pa}$ fraction is free of any ${ }^{233} \mathrm{U}$. Indeed, the presence of any ${ }^{233} \mathrm{U}$ in the Pa fraction or so called " ${ }^{233} \mathrm{U}$ bleeding" would interfere the counting on mass 233 (Choi et al., 2001; Pichat et al., 2004).

In spite of an efficient chromatographic separation that leaves only an insignificant residual $\mathrm{U}$ amount in the $\mathrm{Pa}$ fraction, the contribution of ${ }^{233} \mathrm{U}$ bleeding on the 233 peak in the $\mathrm{Pa}$ fraction was monitored for each sample and estimated following Eq. (1):

$n^{233} \mathrm{~Pa}_{\text {final }}=n^{233}(\mathrm{~Pa}, \mathrm{U})_{\text {sple }}-\left\{\left(\frac{n^{236} \mathrm{U}_{\text {sple }}}{n^{236} \mathrm{U}_{\text {spike }}}\right) \times n^{233}(\mathrm{~Pa}, \mathrm{U})_{\text {sple }}\right\}$

Where $n$ is the number of counts on the masses 233 and 236, and the sub-scripts sple and spike refer to sample (the $\mathrm{Pa}$ fraction) and ${ }^{236} \mathrm{U}$ spike respectively. The estimate of bleeding is based here on the counts of uranium found in the $\mathrm{Pa}$ fraction and not on the measurements of the $\mathrm{U}$ ratios in the $\mathrm{U}$ fractions, preventing us to compare to the literature values (Choi et al., 2001; Pichat et al., 2004; Thomas et al., 2006).

Most of the $\mathrm{Pa}$ analyses were not affected by $\mathrm{U}$ bleeding. Indeed, the ${ }^{233} \mathrm{U}$ bleeding exceeded $0.5 \%$ of the total $\mathrm{U}$ in the $\mathrm{Pa}$ fraction for 10 samples only (reaching $11 \%$ for A3-77, $400 \mathrm{~m}$ depth) but less than $0.01 \%$ in the remaining samples. 
In case of significant bleeding (above $0.5 \%$ ), the aforementioned correction (Eq. 1) was applied.

All the dissolved ${ }^{231} \mathrm{~Pa}$ samples were corrected for the ingrowth from the uranium, which was co-precipitated with $\mathrm{MnO}_{2}$, assuming a maximum of $5 \%$ of co-precipitated $\mathrm{U}$ in the samples (Roy-Barman, personal communication). The mean U-decay corrections vary from $0.22 \%$ (B11 measured 767 days after sampling) to $0.95 \%$ (A3-77, measured 827 days after sampling).

\subsubsection{Uncertainties and blanks}

Uncertainties for ${ }^{231} \mathrm{~Pa}$ concentrations, estimated by isotope dilution, were propagated at the $2 \sigma$ level and include the instrument statistical error, carry-over correction, mass bias, spike contributions and overall procedural blanks. Corrections for the ${ }^{232} \mathrm{Th}$ tailing and ${ }^{233} \mathrm{U}$ bleeding were also taken into account.

For the dissolved samples, the procedural blanks (Table 2) were estimated by analysing (as for a sample, although not spiked) the co-precipitated filters (of two types: Durapore and Versapore) achieved on-board, using 101 ultra-pure water and the same reactants and reagents as for the samples. Distinguishing contamination due to the use of one type of filters with respect to the other was not statistically significant. The blanks for the particles (Table 2) were achieved using Versapore filters. They were generally close to the background noise. The detection limit was estimated at $1.2 \mathrm{fg}$ of ${ }^{231} \mathrm{~Pa}$ and corresponds to three times the standard deviation based on two blanks for particles $(N=2)$.

Although we could not establish a significant statistic on our blank values, they are in the range of those gathered from the literature (Choi et al., 2001; Moran et al., 2002; Edmonds et al., 2004) whatever the extraction method (co-precipitation with Fe or Mn-Ox, filtration or siphoning-off).

The overall yields obtained for ${ }^{231} \mathrm{~Pa}$ are reported in Table 1 and for Th isotopes in Venchiarutti et al. (2008) and are in the range previously reported in the literature (Choi et al., 2001; Thomas et al., 2006).

\section{Results}

In seawater, most of the ${ }^{230} \mathrm{Th}$ and ${ }^{231} \mathrm{~Pa}$ are produced by the radioactive decay of the soluble and homogeneously distributed ${ }^{234} \mathrm{U}$ and ${ }^{235} \mathrm{U}$ respectively, providing the authigenic fraction of these radionuclides in any given sample. However, an accurate determination of this fraction requires the correction of the measured value from the detrital contribution which is supported by the $\mathrm{U}$ already contained in the particles. This latter is the lithogenic fraction of these radionuclides in the same sample. The lithogenic contribution can be critical in areas receiving strong lithogenic inputs.
Here, we estimated the ${ }^{230} \mathrm{Th}$ and ${ }^{231} \mathrm{~Pa}$ scavenged from seawater and termed as "unsupported" (or in excess) ${ }^{230} \mathrm{Th}_{\mathrm{xs}}$ and ${ }^{231} \mathrm{~Pa}_{\mathrm{xs}}$, following the Eqs. (2 and 3):

${ }^{230} \mathrm{Th}_{\mathrm{xs}}={ }^{230} \mathrm{Th}_{\text {measured }}-{ }^{232} \mathrm{Th}_{\text {measured }} \times\left(\frac{{ }^{230} \mathrm{Th}}{{ }^{232} \mathrm{Th}}\right)_{\text {litho }}$

where $\left({ }^{230} \mathrm{Th} / 232 \mathrm{Th}\right)_{\text {litho }}=4.4 \times 10^{-6} \mathrm{~mol} \mathrm{~mol}^{-1}$ based on Roy-Barman et al. (2002).

${ }^{231} \mathrm{~Pa}_{\mathrm{xs}}={ }^{231} \mathrm{~Pa}_{\text {measured }}-\left(\frac{{ }^{235} \mathrm{U}}{{ }^{238} \mathrm{U}}\right)_{\text {natural }} \times\left(\frac{{ }^{238} \mathrm{U}}{{ }^{232} \mathrm{Th}}\right)_{\text {litho }}$

$\times{ }^{232} \mathrm{Th}_{\text {measured }}$

The mean natural activity ratio ${ }^{235} \mathrm{U} /{ }^{238} \mathrm{U}=0.04605$ (Scholten et al., 1995, 2005; Moran et al., 2005) is applied in Eq. (3), ${ }^{238} \mathrm{U} /{ }^{232} \mathrm{Th}$ crustal activity ratio has been measured in different locations and varies from $0.8 \pm 0.2$ (Anderson et al., 1990) in the Pacific, $0.7 \pm 0.2$ in the Atlantic (Scholten et al., 2008) and $0.4 \pm 0.1$ south of the Antarctic Polar Front (Walter et al., 1997). We used here a value of ${ }^{238} \mathrm{U}^{232} \mathrm{Th}=0.8 \pm 0.2$ (Anderson et al., 1990) to estimate ${ }^{231} \mathrm{~Pa}_{\mathrm{xs}}$ in the wake of Kerguelen.

Dissolved and particulate ${ }^{231} \mathrm{~Pa}_{\mathrm{xs}}$ concentrations on and off the Kerguelen plateau are reported in Tables 3 and 4 , and in Figs. 2, 5 and 6 and expressed in $\mathrm{dpm} \mathrm{m}^{-3}$. All the ${ }^{231} \mathrm{~Pa}_{\mathrm{xs}} / 230 \mathrm{Th}_{\mathrm{xs}}$ ratios reported in Tables 3 and 4 and represented in Figs. 3 and 4 are activity ratios.

Most of the dissolved ${ }^{231} \mathrm{~Pa}_{\mathrm{xs}}$ concentrations and ${ }^{231} \mathrm{~Pa}_{\mathrm{xs}}$ ${ }^{230} \mathrm{Th}_{\mathrm{xs}}$ ratios are in the range previously observed in the South-West Indian Basin (Thomas et al., 2006), in the Equatorial Atlantic (Choi et al., 2001; Moran et al., 2002) or in the South Atlantic (Rutgers van der Loeff and Berger, 1993; Walter et al., 2001).

Radionuclide concentrations in particles (Tables 3 and 4) are consistent with values found in the Labrador Sea (Moran et al., 2002) but somewhat lower than values obtained in the South Atlantic, south of the Polar Front by Rutgers van der Loeff and Berger (1993). Particulate ${ }^{231} \mathrm{~Pa}_{\mathrm{xs}}{ }^{230} \mathrm{Th}_{\mathrm{xs}}$ ratios (Fig. 4) are in the range of the particulate ratios observed in the Southern Ocean (Walter et al., 2001).

On average, lithogenic contributions represent $2 \%$ and $1 \%$ of the dissolved and particulate ${ }^{231} \mathrm{~Pa}_{\mathrm{xs}}$ concentrations respectively. The highest lithogenic contributions were observed at $\mathrm{C} 1$ (50 m depth, $10 \%$ contribution) for dissolved ${ }^{231} \mathrm{~Pa}_{\mathrm{xs}}$ and at $\mathrm{A} 3-77$ (350 $\mathrm{m}$ depth, $4 \%$ contribution) for ${ }^{231} \mathrm{~Pa}_{\mathrm{xs}}$ in particles.

\subsection{On-plateau stations $(0-560 \mathrm{~m}$ depth $)$}

Dissolved ${ }^{231} \mathrm{~Pa}_{\mathrm{xs}}$ was analyzed at 2 of the 6 onplateau stations (A3-77 and $\mathrm{C} 1$ ) that were studied for ${ }^{230} \mathrm{Th}_{\mathrm{xs}}$ (Tables 3-4 respectively, Fig. 2a, and for ${ }^{230} \mathrm{Th}_{\mathrm{xs}}$, cf. Venchiarutti et al., 2008). At these two stations, dissolved ${ }^{231} \mathrm{~Pa}_{\mathrm{xs}}$ distribution is constant within the uncertainties all 
Table 2. Summary of the different chemical blank contributions to seawater and particle samples, for different types of filters and for the yield tracers ${ }^{229} \mathrm{Th}$ and ${ }^{233} \mathrm{~Pa}$ used for KEOPS samples. $\mathrm{N}$ is the number of samples analysed. For more details, please refer to the text Sect. 2.4.3.

\begin{tabular}{|c|c|c|c|c|c|}
\hline \multirow[t]{2}{*}{ Blank Types } & \multicolumn{2}{|c|}{${ }^{230} \mathrm{Th}(\mathrm{fg})$} & \multicolumn{2}{|c|}{${ }^{231} \mathrm{~Pa}(\mathrm{fg})$} & \multirow[t]{2}{*}{$\mathrm{N}$} \\
\hline & Mean error & Mean error & Mean error & Mean error & \\
\hline $\begin{array}{l}\text { Filter blanks (Versapore } \varnothing 293 \mathrm{~mm})+ \text { reactants } \\
\text { (contribution to particles) }\end{array}$ & 5.7 & 2.3 & 0.30 & 0.19 & 2 \\
\hline $\begin{array}{l}\text { Filter blanks (Durapore) }+ \text { reactants } \\
\text { (contribution to dissolved) }\end{array}$ & 1.21 & 0.29 & 1.75 & 0.29 & 1 \\
\hline $\begin{array}{l}\text { Filter blanks (Versapore } 2)+ \text { reactants } \\
\text { (contribution to dissolved) }\end{array}$ & 1.24 & 0.8 & 0.55 & 0.27 & 1 \\
\hline 229 Th Spike blank & 0.8 & 70.4 & \multicolumn{2}{|c|}{ No contribution } & 4 \\
\hline 233 Pa Spike blank (second spike, AWI) & 0.32 & 0.11 & 1.28 & 0.15 & 4 \\
\hline
\end{tabular}

Table 3. Kerguelen plateau (A3-77) and off-plateau (C11) stations: dissolved and particulate ${ }^{231} \mathrm{~Pa}_{\mathrm{xs}}$ concentrations in $\mathrm{dpm}^{-3}$ and corresponding ${ }^{231} \mathrm{~Pa}_{\mathrm{xs}}{ }^{230} \mathrm{Th}_{\mathrm{xs}}$ activity ratios. Oiso (as Niskin number) stands here for the ship seawater intake (OISO program). For ${ }^{230} \mathrm{Th}$ and ${ }^{231} \mathrm{~Pa}$ lithogenic contributions, please refer to Sect. 3 of the present text. Errors $(2 \sigma)$ are further described in Sect. 2.4.3. All the activities that fall outside the sensible values (e.g. negative values) are discarded.

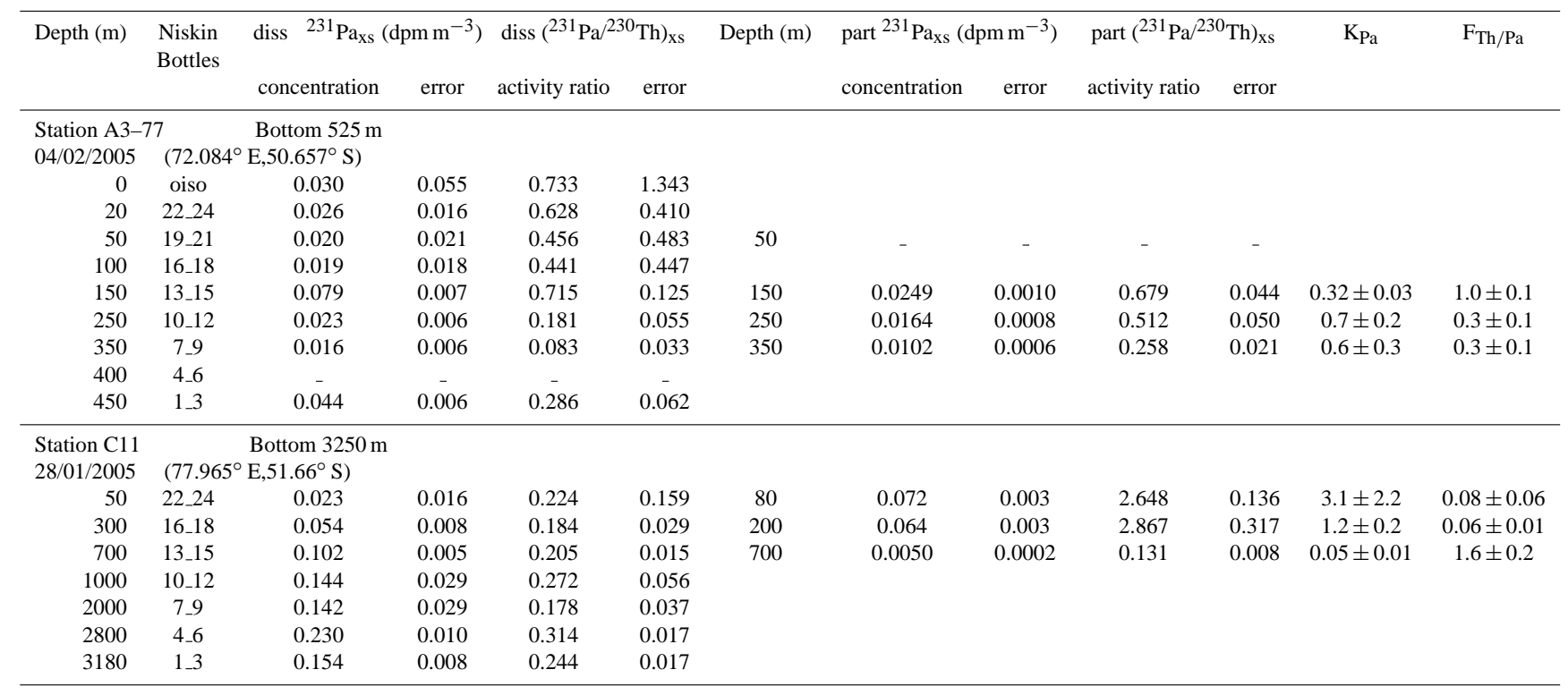

along the water column (Fig. 2a). However, a surprising maximum of dissolved ${ }^{231} \mathrm{~Pa}_{\mathrm{xs}}\left(0.079 \mathrm{dpm} \mathrm{m}^{-3}\right)$ is observed at $150 \mathrm{~m}$ depth at the plateau station A3-77 (Fig. 2a). Most of the dissolved ${ }^{231} \mathrm{~Pa}_{\mathrm{xs}} /{ }^{230} \mathrm{Th}_{\mathrm{xs}}$ ratios are above their production ratio of 0.093 (Fig. 3a) throughout the water column at stations $\mathrm{A} 3-77$ and $\mathrm{C} 1$.

The average ${ }^{231} \mathrm{~Pa}_{\mathrm{xs}}$ concentration in particles (Table 3), measured only at station A3-77, is $0.017 \mathrm{dpm} \mathrm{m}^{-3}$ representing about $43 \%$ of the total ${ }^{231} \mathrm{~Pa}_{\mathrm{xs}}$ concentration at this station. Particulate ${ }^{231} \mathrm{~Pa}_{\mathrm{xs}}{ }^{230} \mathrm{Th}_{\mathrm{xs}} \geq 0.093$ (Fig. 4) is observed at this latter station, with a decrease of the ratio with increasing depth.

\subsection{Off-plateau stations ( $(0-3275 \mathrm{~m}$ depth)}

Dissolved ${ }^{231} \mathrm{~Pa}_{\mathrm{xs}}$ was measured at 2 out of the 4 off-plateau stations (C11 and B11 stations, Fig. 2b) that were analysed for ${ }^{230} \mathrm{Th}_{\mathrm{xs}}$. These stations are considered as representative of "open ocean" or HNLC stations.

Dissolved ${ }^{231} \mathrm{~Pa}$ concentrations (Fig. 2b) increase almost linearly with depth between $50 \mathrm{~m}$ depth and down to $1000 \mathrm{~m}$ depth $\left(\sigma_{0}=27.65 \mathrm{~kg} \mathrm{~m}^{-3}\right)$, in agreement with what was already observed in the Southern Ocean (Rutgers van der Loeff and Berger, 1993; Chase et al., 2003). Between $1000 \mathrm{~m}$ and $2500 \mathrm{~m}$ (Figs. $2 \mathrm{~b}$ and 5, 27.83< $\sigma_{0}<27.65 \mathrm{~kg} \mathrm{~m}^{-3}$ ) along the eastern flank of the plateau, dissolved ${ }^{231} \mathrm{~Pa}$ at stations B11 
Table 4. Kerguelen on and off plateau stations: dissolved (left) and particulate (right) ${ }^{231} \mathrm{~Pa}_{\mathrm{xs}}$ concentrations in $\mathrm{dpm} \mathrm{m}^{-3}$ and corresponding ${ }^{231} \mathrm{~Pa}_{\mathrm{xs}} /{ }^{230} \mathrm{Th}_{\mathrm{xs}}$ activity ratios. For ${ }^{230} \mathrm{Th}$ and ${ }^{231} \mathrm{~Pa}$ lithogenic contributions, please refer to Sect. 3 of the present text respectively. Errors $(2 \sigma)$ are further described in Sect. 2.4.3.

\begin{tabular}{|c|c|c|c|c|c|c|c|c|c|c|c|}
\hline \multirow[t]{2}{*}{ Depth (m) } & \multirow[t]{2}{*}{ Niskins } & \multicolumn{2}{|c|}{ diss ${ }^{231} \mathrm{~Pa}_{\mathrm{xs}}\left(\mathrm{dpm} \mathrm{m}^{-3}\right)$} & \multicolumn{2}{|c|}{$\operatorname{diss}\left({ }^{231} \mathrm{~Pa} /{ }^{230} \mathrm{Th}\right)_{\mathrm{Xs}}$} & \multirow[t]{2}{*}{ In-situ pumps } & \multirow[t]{2}{*}{ Depth (m) } & \multicolumn{2}{|c|}{ part ${ }^{231} \mathrm{~Pa}_{\mathrm{xs}}\left(\mathrm{dpm} \mathrm{m}^{-3}\right)$} & \multicolumn{2}{|c|}{ part $\left({ }^{231} \mathrm{~Pa} /{ }^{230} \mathrm{Th}\right)_{\mathrm{xs}}$} \\
\hline & & concentration & error & activity ratio & error & & & concentration & error & activity ratio & error \\
\hline \multicolumn{6}{|c|}{$\begin{array}{l}\text { Station B11 Bottom : } 3275 \mathrm{~m} \\
\left(29 / 01 / 2005,76.98^{\circ} \mathrm{E}, 50.52^{\circ} \mathrm{S}\right)\end{array}$} & \multicolumn{6}{|c|}{$\begin{array}{l}\text { Station A11 Bottom : } 2600 \mathrm{~m} \\
\left(21 / 01 / 2005,74.007^{\circ} \mathrm{E}, 49.013^{\circ} \mathrm{S}\right)\end{array}$} \\
\hline 0 & oiso & 0.218 & 0.026 & 3.031 & 0.562 & & & & & & \\
\hline 50 & $22 \_24$ & 0.065 & 0.008 & 0.709 & 0.112 & & & & & & \\
\hline 150 & $19 \_21$ & 0.050 & 0.007 & 0.298 & 0.047 & pis 001 & 200 & 0.0084 & 0.0005 & 0.326 & 0.040 \\
\hline 300 & $16 \_18$ & 0.085 & 0.006 & 0.284 & 0.026 & pis 001 & 300 & 0.0084 & 0.0003 & 0.480 & 0.043 \\
\hline 700 & $13 \_15$ & 0.187 & 0.011 & 0.390 & 0.028 & pis 001 & 700 & 0.0119 & 0.0005 & 0.249 & 0.015 \\
\hline 1000 & $10 \_12$ & 0.211 & 0.008 & 0.296 & 0.018 & pis 001 & 1500 & 0.0105 & 0.0004 & 0.143 & 0.006 \\
\hline 2000 & 7_9 & 0.303 & 0.012 & 0.390 & 0.023 & & & & & & \\
\hline 2800 & 4_6 & 0.205 & 0.010 & 0.235 & 0.014 & & & & & & \\
\hline 3146 & $1 \_3$ & 0.309 & 0.012 & 0.311 & 0.015 & & & & & & \\
\hline \multicolumn{6}{|c|}{$\begin{array}{c}\text { Station C1 } \quad \text { Bottom : } 150 \mathrm{~m} \\
\left(08 / 02 / 2005,73.883^{\circ} \mathrm{E}, 53.186^{\circ} \mathrm{S}\right)\end{array}$} & \multicolumn{6}{|c|}{$\begin{array}{l}\text { Station Kerfix Bottom : } 1676 \mathrm{~m} \\
\left(10 / 02 / 2005,68.435^{\circ} \mathrm{E}, 50.68^{\circ} \mathrm{S}\right)\end{array}$} \\
\hline 0 & oiso & 0.030 & 0.030 & 1.341 & 1.357 & pis 006 & 100 & 0.0051 & 0.0006 & 0.503 & 0.326 \\
\hline 30 & $18 \_20$ & 0.029 & 0.007 & 0.596 & 0.145 & pis 006 & 200 & 0.0064 & 0.0003 & 0.578 & 0.055 \\
\hline 50 & $13 \_15$ & 0.017 & 0.007 & 0.353 & 0.160 & pis 006 & 500 & 0.0041 & 0.0002 & 0.158 & 0.010 \\
\hline 100 & $6 \_8$ & 0.028 & 0.008 & 0.460 & 0.143 & pis 006 & 800 & 0.0103 & 0.0006 & 0.309 & 0.022 \\
\hline 130 & $1 \_3$ & 0.041 & 0.006 & 0.725 & 0.140 & pis 006 & 1200 & 0.0080 & 0.0005 & 0.163 & 0.010 \\
\hline
\end{tabular}
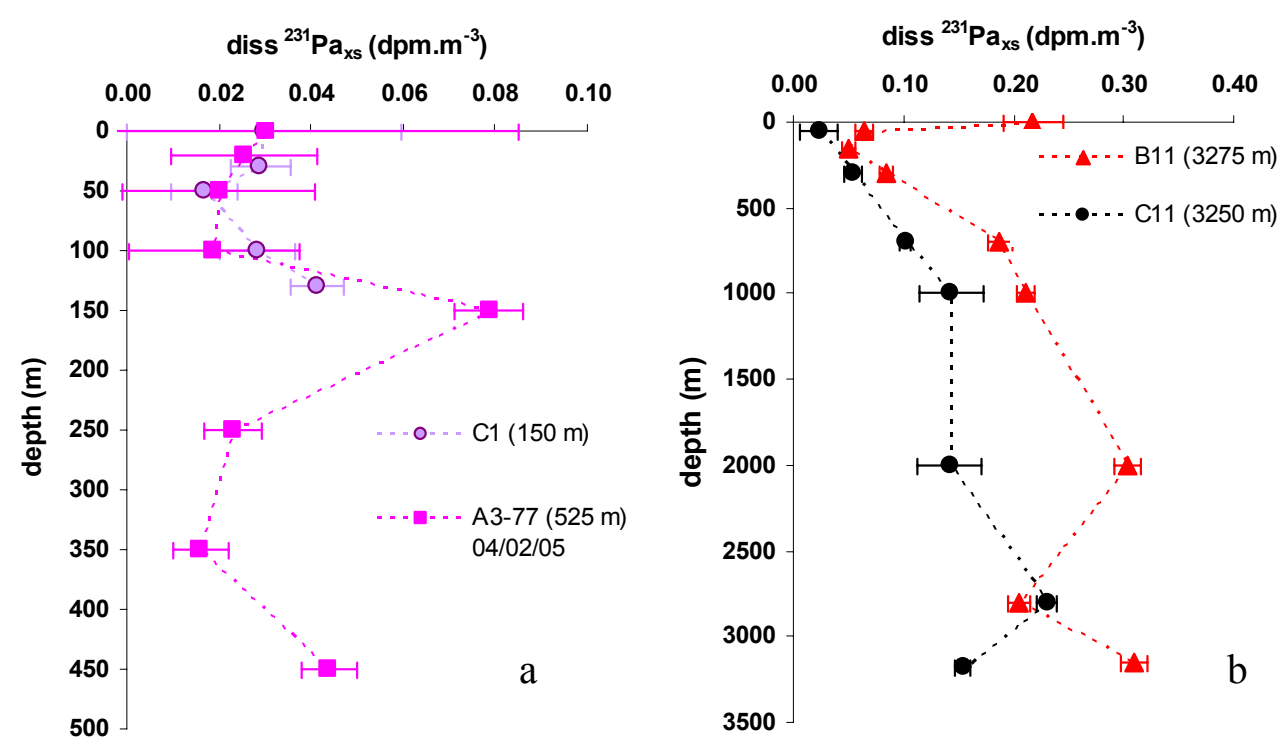

Fig. 2. Dissolved ${ }^{231} \mathrm{~Pa}_{\mathrm{xs}}$ vertical profiles in $\mathrm{dpm} \mathrm{m}^{-3}$. (a) at the Kerguelen plateau stations. (b) at the off-plateau stations. The error bars are represented here at the $2 \sigma$ uncertainty (as described in Sect. 2.4.3). Bottom depths (in $\mathrm{m}$ ) at all the stations are indicated into brackets. The concentrations may be converted from $\mathrm{dpm} \mathrm{m}^{-3}$ assuming a correction of the density of seawater (i.e. $\rho=1.027 \mathrm{~kg} \mathrm{~m}^{-3}$ ), we have for both ${ }^{230}$ Thxs $\left(1 \mathrm{fg} \mathrm{kg}^{-1}=0.047 \mathrm{dpm} \mathrm{m}^{-3}\right)$ and ${ }^{231} \mathrm{Paxs}\left(1 \mathrm{fg} \mathrm{kg}^{-1}=0.1078 \mathrm{dpm} \mathrm{m}^{-3}\right)$, and for ${ }^{232} \mathrm{Th}\left(1 \mathrm{pg} \mathrm{kg}^{-1}=0.00025 \mathrm{dpm} \mathrm{m}^{-3}\right)$.

and C11 exhibits depleted profiles deviating from the linear distribution with depth. Close to the seafloor (Figs. 2b and $5, \sigma_{0} \leq 27.83 \mathrm{~kg} \mathrm{~m}^{-3}$ ), dissolved ${ }^{231} \mathrm{~Pa}_{\mathrm{xs}}$ concentrations decrease at station $\mathrm{C} 11$ whereas they increase at station B11.

Particulate ${ }^{231} \mathrm{~Pa}_{\mathrm{xs}}$ concentrations vary from $0.0041 \mathrm{dpm} \mathrm{m}^{-3}$ at $500 \mathrm{~m}$ at Kerfix to $0.072 \mathrm{dpm} \mathrm{m}^{-3}$ at $80 \mathrm{~m}$ at $\mathrm{C} 11$ (Tables 3 and 4). Particulate ${ }^{231} \mathrm{~Pa}_{\mathrm{xs}}$ contributes around $20 \%$ of total ${ }^{231} \mathrm{~Pa}_{\mathrm{xs}}$, in deep waters. This particulate fraction dominates over the dissolved one in the upper $100 \mathrm{~m}$ of the water column only. For example, at station $\mathrm{C} 11$, about $75 \%$ of the total ${ }^{231} \mathrm{~Pa}$ is on particles in the surface waters.

Dissolved ${ }^{231} \mathrm{~Pa}_{\mathrm{xs}} /{ }^{230} \mathrm{Th}_{\mathrm{xs}}$ ratios are relatively constant with depth and above the production activity ratio of 0.093 (Fig. 3b). They display a few maxima in the surface waters, reaching 3.03 at station B11 (Table 4). Particulate ${ }^{231} \mathrm{~Pa}_{\mathrm{xs}} /{ }^{230} \mathrm{Th}_{\mathrm{xs}}$ ratios (Fig. 4) show a clear dependence with depth, displaying some maxima in surface waters (with a 

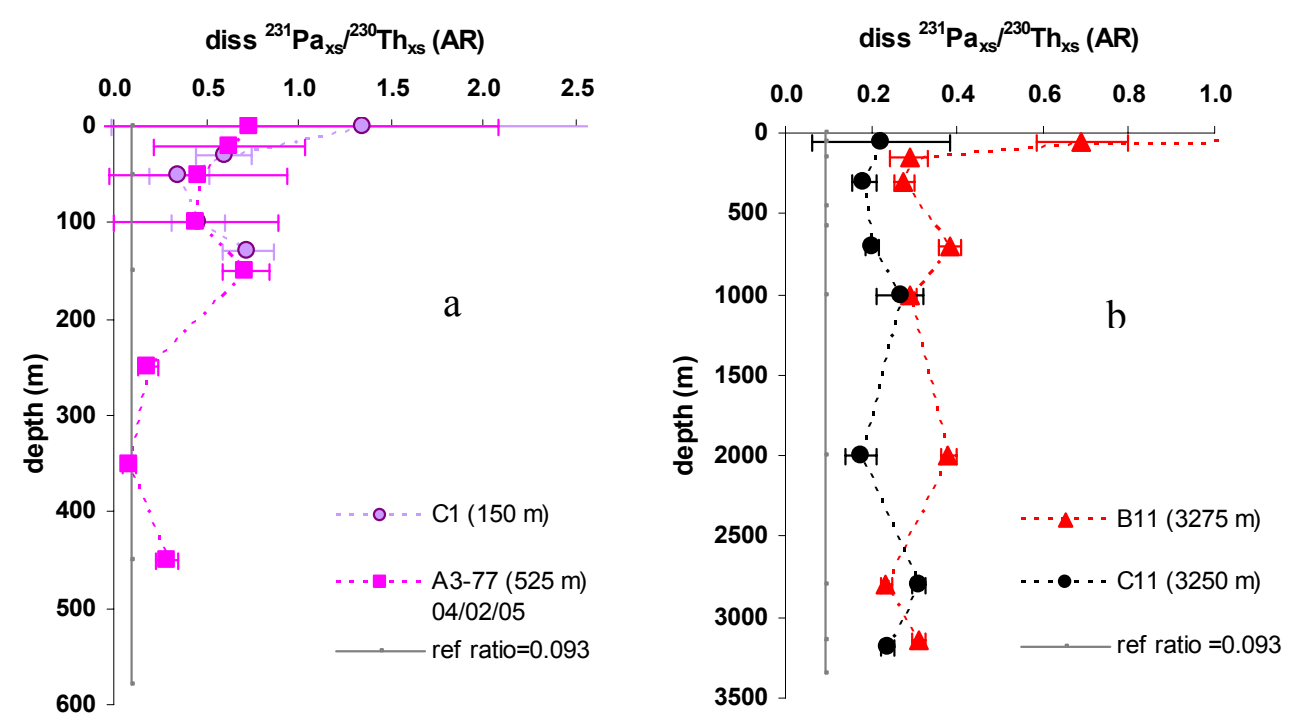

Fig. 3. Dissolved ${ }^{231} \mathrm{~Pa}_{\mathrm{xs}} /{ }^{230} \mathrm{Th}_{\mathrm{xs}}$ activity ratio vertical profiles. (a) on the Kerguelen plateau. (b) off-plateau. The error bars are represented here at the $2 \sigma$ uncertainty (as described in Sect. 2.4.3). The grey line represents the ${ }^{231} \mathrm{~Pa} /{ }^{230} \mathrm{Th}$ production activity ratio $=0.093$. Bottom depths are indicated into brackets. Note that for station B11 the high dissolved ratio (3.03 \pm 0.6$)$ at the surface is not represented in this figure.

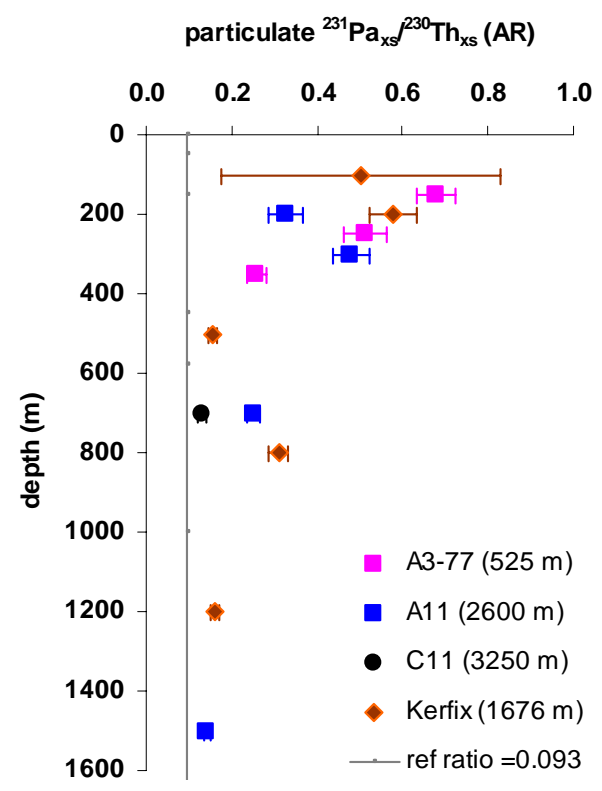

Fig. 4. Distribution of particulate ${ }^{231} \mathrm{~Pa}_{\mathrm{xs}} /{ }^{230} \mathrm{Th}_{\mathrm{xs}}$ activity ratios ( $2 \sigma$ error bars) with depth, on and off the Kerguelen plateau. For grey line and bottom depths, see caption of Fig. 3. Note that for station $\mathrm{C} 11$ the high particulate ratios (2.6 and 2.9) at the surface are not represented in this figure.

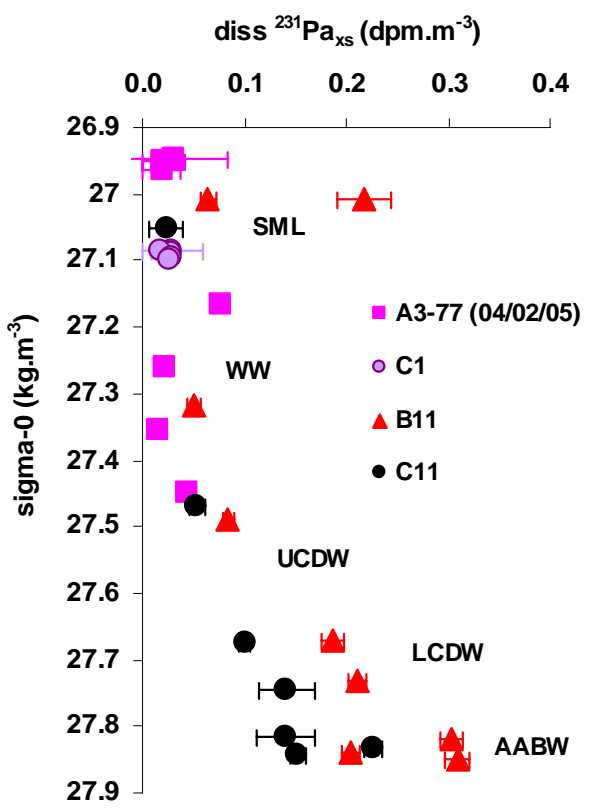

Fig. 5. Distributions of dissolved ${ }^{231}$ Paxs concentrations in $\mathrm{dpm} \mathrm{m} \mathrm{m}^{-3}$ with sigma-0 density $\left(\mathrm{kg} \mathrm{m}^{-3}\right)$ on and off the Kerguelen plateau. The main water masses are indicated (SML stands for Surface Mixed Layer; see as well caption of Fig. 1 for the other abbreviations). 
mean value of $\sim 2.76$ between $80 \mathrm{~m}$ and $200 \mathrm{~m}$ at station C11, Table 3 ) and then decreasing values with increasing depth.

\section{Discussion}

Here, we aimed at determining the mechanisms involved in $\mathrm{Pa}$ and Th scavenging, fractionation and their resulting distributions in seawater and particles in the wake of Kerguelen.

\subsection{Fractionation of ${ }^{231} \mathrm{~Pa}$ and ${ }^{230} \mathrm{Th}$ in the wake of Kerguelen}

Dissolved ${ }^{231} \mathrm{~Pa}_{\mathrm{xs}}{ }^{230} \mathrm{Th}_{\mathrm{xs}}$ activity ratio does not change significantly with depth on and off the Kerguelen plateau (Fig. 3). Contrastingly, particulate ${ }^{231} \mathrm{~Pa}_{\mathrm{xs}} /{ }^{230} \mathrm{Th}_{\mathrm{xs}}$ activity ratio decreases by a factor of $\sim 2$ between shallow and deep waters whatever the station (Fig. 4). These variations could reflect changes in the rates of exchange processes (adsorption/desorption, aggregation/disaggregation) between particles and seawater and/or in the particles chemistry (composition or particle alteration).

The fractionation factor (noted $F_{\mathrm{Th} / \mathrm{Pa}}$ ) is a good tool to investigate the influence of particle composition on the scavenging and fractionation of ${ }^{231} \mathrm{~Pa}$ and ${ }^{230} \mathrm{Th}$, assuming chemical equilibrium between dissolved and particulate phases. It provides information on the element reactivity according to the particle composition (Walter et al., 1999; Guo et al., 2002; Luo and Ku, 2004; Chase et al., 2002 and 2004) and is defined as follows:

$$
F_{\mathrm{Th} / \mathrm{Pa}}=\frac{\left({ }^{230} \mathrm{Th} /{ }^{231} \mathrm{~Pa}\right)_{\mathrm{part}}}{\left({ }^{230} \mathrm{Th} /{ }^{231} \mathrm{~Pa}\right)_{\text {diss }}}=\frac{K_{\mathrm{Th}}}{K_{\mathrm{Pa}}}
$$

Where $K_{\mathrm{Th}}$ and $K_{\mathrm{Pa}}$ are the partition coefficients for ${ }^{230} \mathrm{Th}$ and ${ }^{231} \mathrm{~Pa}$ respectively, defined as the activity ratio between particle and seawater distributions. Note that both activities are here expressed as dpm of Th and Pa per $\mathrm{m}^{3}$ of seawater (Scholten et al., 1995; Venchiarutti et al., 2008; Roy-Barman, 2009) and not related to the mass of particles per litre of seawater (Chase et al., 2002), since no "extensive" study of the particulate composition or particle size/surface area was carried out during KEOPS cruise. Consequently, the partition coefficients determined here are dependent on the particles concentration and will change if particle mass changes.

In most of the open ocean, Th is preferentially scavenged over Pa yielding a fractionation factor $F_{\mathrm{Th} / \mathrm{Pa}}$ of roughly 10 (Anderson et al., 1983a). In the Kerguelen area (Table 3), $F_{\mathrm{Th} / \mathrm{Pa}}$ values are very low, ranging from $0.06 \pm 0.01(\mathrm{C} 11$, $200 \mathrm{~m})$ to $1.6 \pm 0.2(\mathrm{C} 11,700 \mathrm{~m}) . F_{\mathrm{Th} / \mathrm{Pa}}$ close to 1 is typically observed when opal abundance is high (Walter et al., 1997; Chase et al., 2002; Scholten et al., 2005, 2008) reflecting the high affinity of Pa for opal.

The low $F_{\mathrm{Th} / \mathrm{Pa}}$ values reflect the high affinity of ${ }^{231} \mathrm{~Pa}$ for particulate matter. Indeed, in the Kerguelen area, $K_{\mathrm{Pa}}$ values range from $0.05 \pm 0.01(\mathrm{C} 11,700 \mathrm{~m})$ to $3.1 \pm 2.2(\mathrm{C} 11$,
$80 \mathrm{~m}$ ), with an average value of 0.86 (Table 3 ). This is almost two orders of magnitude larger than the $K_{\mathrm{Pa}}$ values observed in areas where biogenic silica (BSi) is not prevalent in the particulate matter, like in the Equatorial Pacific and SouthEast Atlantic ( 0.01-0.04; Anderson et al., 1983a; Scholten et al., 2008). This high affinity of ${ }^{231} \mathrm{~Pa}$ for particulate matter in the Kerguelen area is consistent with the high BSi values recorded during KEOPS cruise, with about $5 \mu \mathrm{mol} \mathrm{L}{ }^{-1}$ over the Kerguelen plateau and $\sim 2 \mu \mathrm{mol} \mathrm{L}^{-1}$ at the off-plateau stations (Mosseri et al., 2008; Fripiat et al., 2011), compared with the low BSi concentrations $<0.5 \mu \mathrm{mol} \mathrm{L} \mathrm{L}^{-1}$ found in the Equatorial Pacific (Leynaert et al., 2001) and in the SouthEast Atlantic (Bishop et al., 1978).

Moreover, the observed $F_{\mathrm{Th} / \mathrm{Pa}}<1$ of the Kerguelen area suggests that high opal abundance favours adsorption of ${ }^{231} \mathrm{~Pa}$ onto particles with more efficiency than ${ }^{230} \mathrm{Th}$, thereby producing high particulate ${ }^{231} \mathrm{~Pa}_{\mathrm{xs}}{ }^{230} \mathrm{Th}_{\mathrm{xs}}$ ratios in the euphotic layer. It confirms the enhanced affinity of ${ }^{231} \mathrm{~Pa}$ for opal when opal represents more than $60 \%$ of the particulate matter (Scholten et al., 2005).

Using parameter such as $F_{\mathrm{Th} / \mathrm{Pa}}, K_{\mathrm{Th}}$ or $K_{\mathrm{Pa}}$ to establish a link between the particulate matter composition and its effect on $\mathrm{Pa}$ and $\mathrm{Th}$ fractionation, we implicitly assume that $\mathrm{Pa}$ and Th have reached a chemical equilibrium between the dissolved and the particulate phases. However, such equilibrium may not be reached at all the water column depths, especially in the surface waters. Hence, it may not be possible to integrate this fractionation over the whole water column as suggested by Thomas et al. (2006) and Scholten et al. (2008). Therefore, we must remain cautious in our interpretation.

Nevertheless, the low $F_{\mathrm{Th} / \mathrm{Pa}}$ values and relationship between $K_{\mathrm{Pa}}$ and BSi confirm that ${ }^{231} \mathrm{~Pa}$ and ${ }^{230} \mathrm{Th}$ fractionation in the Kerguelen area appears driven by the biogenic opal content of the particles. This is consistent with the high abundance of large diatoms in the euphotic layer of the Kerguelen area (Armand et al., 2008; Carlotti et al., 2008).

\subsection{Evidence of boundary scavenging along the eastern slope of the Kerguelen plateau}

Along the eastern escarpment of the Kerguelen plateau, cold Antarctic subsurface and deep waters are entrained by the northward branch of the Fawn Trough Current (Fig. 1) from the eastern station C11 toward B11 (Park et al., 2008 and Mongin et al., 2008). In the deep waters $\left(\sigma_{0}=27.63-\right.$ $27.84 \mathrm{~kg} \mathrm{~m}^{-3}$, i.e. from $700 \mathrm{~m}$ depth to the bottom), ${ }^{231} \mathrm{~Pa}_{\mathrm{xs}}$ concentration profiles differ (Figs. 2b and 5), while the deep water masses of these stations have similar $\theta$-S characteristics (Park et al., 2008; Venchiarutti et al., 2008). The ${ }^{231} \mathrm{~Pa}_{\mathrm{xs}}$ depletion is more pronounced at $\mathrm{C} 11$ than at $\mathrm{B} 11$. These features are qualitatively similar to those observed for the ${ }^{230} \mathrm{Th}_{\mathrm{xs}}$ profiles at the same stations (Venchiarutti et al., 2008).

As for ${ }^{230} \mathrm{Th}$, we attribute the ${ }^{231} \mathrm{~Pa}_{\mathrm{xs}}$ depletion to an intense boundary scavenging in the water flowing along the 
eastern escarpment of the plateau, possibly due to particle re-suspension and/or nepheloid layers in the deep and bottom waters (Venchiarutti et al., 2008). Indeed, it has been shown (notably for ${ }^{210} \mathrm{~Pb}$ ) that particles supplied from the seafloor with nepheloid layers can have a strong impact on the radionuclide scavenging in the deep ocean (Nozaki et al., 1997; Okubo et al., 2007; Turnewitsch et al., 2008). However, the exact processes yielding this bottom scavenging remain to be determined. Indeed, if reversible equilibrium only is determining the dissolved and particulate $\mathrm{Pa}$ distribution when particles fall through the water column, re-suspended particles should be at equilibrium with bottom waters and hence particle re-suspension should not produce further $\mathrm{Pa}$ scavenging.

Although C11 seems located upstream of B11 (Fig. 1), some of the $\mathrm{C} 11$ deep waters have already interacted with the waters flowing at the contact of the slope, and likely with the sediments deposited on it (Park et al., 2008). This interaction of the deep waters with the eastern slope of the Kerguelen plateau is also imprinted in their $\mathrm{Nd}$ isotopic signature (Jeandel et al., 2011b). This is not the case for B11 deep waters, located in the core of the Fawn Trough and east off the Kerguelen plateau (Park et al., 2008). This explains the lower radionuclide concentrations at $\mathrm{C} 11$ compared to B11 (Figs. 2b and 5).

Comparing the mean dissolved ${ }^{231} \mathrm{~Pa}_{\mathrm{xs}}$ and ${ }^{230} \mathrm{Th}_{\mathrm{xs}}$ concentrations between $700 \mathrm{~m}$ and $2800 \mathrm{~m}$ depth at B11 and $\mathrm{C} 11$, taking B11 as the reference station from the open-ocean (not affected by scavenging along the Kerguelen plateau slope), we estimated that this margin effect leads to a scavenging of $\Delta{ }^{231} \mathrm{~Pa}_{\mathrm{xs}}=37 \pm 4 \%$ and $\Delta{ }^{230} \mathrm{Th}_{\mathrm{xs}}=10 \pm 0.3 \%$ between these two stations. Assuming that these depletions are only due to scavenging on particles, the average $F_{\mathrm{Th} / \mathrm{Pa}}$ along the escarpment can be estimated as $\left(\Delta^{230} \mathrm{Th}_{\mathrm{xs}} / \Delta^{231} \mathrm{~Pa}_{\mathrm{xs}}\right) /\left(\left(1-\Delta^{230} \mathrm{Th}_{\mathrm{xs}}\right) /\left(1-\Delta^{231} \mathrm{~Pa}_{\mathrm{xs}}\right)\right)=0.20$. Taking the uncertainties on $\Delta^{230} \mathrm{Th}_{\mathrm{xs}}$ and $\Delta^{231} \mathrm{~Pa}_{\mathrm{xs}}$ into account, we obtain a total range of $F_{\mathrm{Th} / \mathrm{Pa}}=0.16-0.24$. This range is consistent with the $F_{\mathrm{Th} / \mathrm{Pa}}<2$ estimated at $\mathrm{C} 11$ with only one value above 1 , at $700 \mathrm{~m}$ depth at $\mathrm{C} 11$.

These scavenging estimates and low fractionation factor for ${ }^{231} \mathrm{~Pa}_{\mathrm{xs}}$ and ${ }^{230} \mathrm{Th}_{\mathrm{xs}}$ confirm that in an environment dominated by $\mathrm{BSi},{ }^{231} \mathrm{~Pa}$ removal is at least as efficient and possibly more efficient than ${ }^{230} \mathrm{Th}$ removal as we inferred in the previous section from the $K_{\mathrm{Pa}}$ and $F_{\mathrm{Th} / \mathrm{Pa}}$ data.

Finally, in the case of the Kerguelen area, the high abundance of opal appears to enhance the "boundary scavenging" effect already generated by the difference in the radionuclide residence times (Anderson et al., 1983b).

\subsection{Scavenging of ${ }^{231} \mathrm{~Pa}$ on the Kerguelen plateau}

We now apply the Kerguelen plateau boundary scavenging model developed for ${ }^{230} \mathrm{Th}$ (Venchiarutti et al., 2008) to ${ }^{231} \mathrm{~Pa}$, in order to determine the ${ }^{231} \mathrm{~Pa}$ scavenging rate over the plateau, the influence of open ocean water advection and thereby the resulting Pa flux down to the sediment.

We assume that between 0 and $500 \mathrm{~m}$, the ${ }^{231} \mathrm{~Pa}$ concentration in the open ocean essentially increases linearly with depth and take the off-plateau station B11 (Fig. 2b) as reference for the open ocean with $\left(\mathrm{d}^{231} \mathrm{~Pa}_{\mathrm{xs}-\mathrm{t}} / \mathrm{dz}\right)=3.4 \times 10^{-4} \mathrm{dpm} \mathrm{m}^{-4}$. In order to estimate $\mathrm{d}^{231} \mathrm{~Pa}_{\mathrm{xs}-\mathrm{t}}$ concentration at $\mathrm{B} 11$, particulate data missing at this station, we consider a value of 0.2 for $K_{\mathrm{Pa}}$ as representative of the affinity of ${ }^{231} \mathrm{~Pa}$ for particulate matter in the upper $500 \mathrm{~m}$ depth of the water column, in an area of the open ocean (i.e. here, out of the plateau) dominated by opal (Rutgers van der Loeff and Berger, 1993).

The vertical dissolved Pa profile over the plateau, derived from Eq. (13) in Venchiarutti et al. (2008), is then given by:

$$
\begin{aligned}
& { }^{231} \mathrm{~Pa}_{\mathrm{xs}-\mathrm{d}}=\frac{P_{231} \mathrm{~Pa}}{S K_{\mathrm{Pa}} A}\left(1-e^{-A z}\right)+\frac{\tau}{S K_{\mathrm{Pa}} A^{2}}\left(\frac{d^{231} P a_{\mathrm{xs}-\mathrm{t}}}{d z}\right) \\
& \left(A z-1+e^{-A z}\right)
\end{aligned}
$$

Where $A$ is a constant defined as $A=\left(\tau\left(1+K_{\mathrm{Pa}}\right) / S K_{\mathrm{Pa}}\right)$, $\tau$ is the transit time of the water at station A3 defined as $\tau=L / u=0.33 \mathrm{y}$, taking an horizontal speed $u$ of $5 \mathrm{~cm} \mathrm{~s}^{-1}$ (mean current velocity measured with moorings, for the stations of the transect $A$, cf. Park et al., 2008) and a distance over the whole plateau $L=520 \mathrm{~km}$ (Venchiarutti et al., 2008). Thus, we estimate the water residence time on the plateau of about 4 months, which may be considered as the lowest value for the water residence time, since this estimate is based on the highest mean current velocity on the whole plateau.

We assume that $\mathrm{Th}$ and $\mathrm{Pa}$ are transported on the plateau at the same particle settling velocity and hence onto the same class of settling particles $\left(S=3000 \mathrm{~m} \mathrm{yr}^{-1}\right.$, Venchiarutti et al., 2008). Over the plateau, we take the mean value $K_{\mathrm{Pa}}=0.56 \pm 0.21$ at station A3-77. The production rate of ${ }^{231} \mathrm{~Pa}$ is $\mathrm{P}=2.44 \times 10^{-3} \mathrm{dpm} \mathrm{m}^{-3} \mathrm{yr}^{-1}$.

Despite the few available data, their general agreement with the modelled profile at station A3 confirms the importance of advection on the distribution of ${ }^{231} \mathrm{~Pa}$ over the plateau (Fig. 6). The model allows us to estimate that the vertical particulate ${ }^{231} \mathrm{~Pa}$ flux settling at $500 \mathrm{~m}$ over the plateau is $S \times\left({ }^{231} \mathrm{~Pa}_{\mathrm{xs}}-\mathrm{p}\right) 500 \mathrm{~m}=84.9 \mathrm{dpm} \mathrm{m}^{-2} \mathrm{yr}^{-1}$ and represents almost 70 times the local in situ production integrated over a $500 \mathrm{~m}$ depth water column. This high ${ }^{231} \mathrm{~Pa}$ flux is possible because the ${ }^{231} \mathrm{~Pa}$ scavenging residence time $\left(h /\left(2 S K_{\mathrm{Pa}}\right) \sim 0.15 \mathrm{yr}\right)$ in the water column is shorter than the residence time of the water on the Kerguelen plateau ( $\sim 0.33 \mathrm{yr})$, thereby allowing an efficient scavenging and because the advected open ocean water has a high ${ }^{231} \mathrm{~Pa}$ content (as in the Surface Mixed Layer and Winter Waters from the off-plateau station B11, Fig. 5).

Hence, the drawdown of the dissolved ${ }^{231} \mathrm{~Pa}$ concentration over the plateau remains limited because advection of open ocean water brings continuously new ${ }^{231} \mathrm{~Pa}$ over the plateau. 


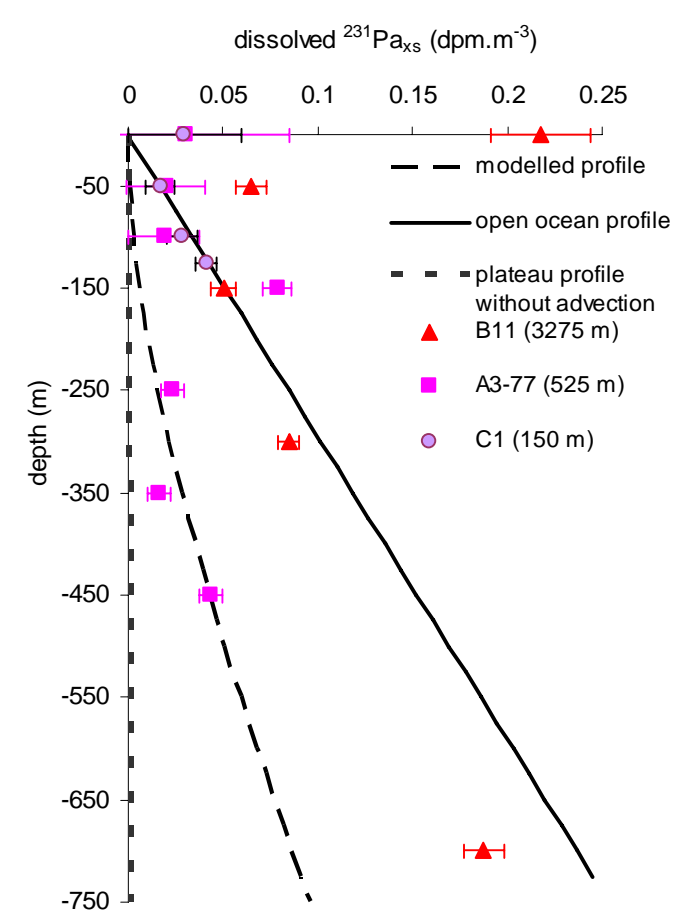

Fig. 6. Advection-scavenging model applied to dissolved ${ }^{231} \mathrm{~Pa}_{\mathrm{xs}}$. The symbols represent the measured dissolved ${ }^{231} \mathrm{~Pa}_{\mathrm{xs}}$ profiles at KEOPS stations. The lines represent: dashed line (scavenging model with advection on the plateau - A3 station - of open-ocean water with ${ }^{231} \mathrm{~Pa}_{\mathrm{xs}}$ concentration increasing with depth), solid bold line (the imposed open-ocean dissolved ${ }^{231} \mathrm{~Pa}_{\mathrm{xs}}$ profile: $\mathrm{B} 11$ chosen here as reference) and dotted line (dissolved ${ }^{231} \mathrm{~Pa}_{\mathrm{xs}}$ profile without advection). Dissolved ${ }^{231} \mathrm{~Pa}_{\mathrm{xs}}$ concentrations at $\mathrm{C} 1$ station are also represented, since they may be representative of advected waters from the south of the Kerguelen plateau (south of Heard Island). Error bars are represented at the $2 \sigma$ value. Bottom depths are indicated into brackets.

If similar scavenging conditions occurred without any advection of open-ocean water, the dissolved ${ }^{231} \mathrm{~Pa}$ concentration should be much lower than observed (Fig. 6, curve "plateau profile without advection", $F=0$ ).

The dissolved ${ }^{231} \mathrm{~Pa}$ concentrations at $\mathrm{C} 1$, nearby Heard Island, is consistent with the open-ocean profile (Fig. 6, solid bold line), suggesting that waters originating from this area may also be a source of ${ }^{231} \mathrm{~Pa}$-rich waters for the central plateau (A3 station), in agreement with Zhang et al. (2008) and Chever et al. (2010).

In the Panama and Guatemala Basins, the lack of Pa-Th fractionation associated with boundary scavenging of ${ }^{230} \mathrm{Th}$ and ${ }^{231} \mathrm{~Pa}$ was explained by a moderately intensified scavenging compared to the open ocean with $F_{\mathrm{Th} / \mathrm{Pa}}<<10$ rather than by a quantitative stripping of ${ }^{231} \mathrm{~Pa}$ and ${ }^{230} \mathrm{Th}$ with $F_{\mathrm{Th} / \mathrm{Pa}}=10$ (Anderson et al., 1983b). In the Kerguelen plateau case, there is both $F_{\mathrm{Th} / \mathrm{Pa}}<<10$ (Table 3) and a strongly intensified scavenging due to the high biological productivity, but not completely reflected in the dissolved
${ }^{230} \mathrm{Th}$ and ${ }^{231} \mathrm{~Pa}$ concentrations due to the effect of advection.

In summary, the ${ }^{231} \mathrm{~Pa}$ data confirm that there is an enhanced scavenging on the plateau, as already observed for ${ }^{230} \mathrm{Th}$ (Venchiarutti et al., 2008). Moreover, ${ }^{231} \mathrm{~Pa}$ concentrations showed that this intensified scavenging on the Kerguelen plateau is due to both particle flux and particle composition effects, leading to a low $\mathrm{Pa} / \mathrm{Th}$ fractionation. However, the "boundary scavenging" model proposed for the Kerguelen plateau in Venchiarutti et al. (2008), is a particular case of boundary scavenging model where the open ocean is infinitely large compared to the ocean margin (Roy-Barman, 2009). Compared to the boundary scavenging created by a large continental margin in the Pacific Ocean as described by Bacon et al. (1988), the strong ${ }^{230} \mathrm{Th}$ and ${ }^{231} \mathrm{~Pa}$ scavenging at Kerguelen (a small spot in the Southern Ocean) should not create a significant depletion of these radionuclides throughout the whole Southern Ocean.

However, these results stress that, even for particulate reactive metals with short residence time in the water column, the effect of lateral advection over the Kerguelen plateau cannot be neglected. Indeed, subsequently to the publication of the boundary scavenging model for the Kerguelen plateau, Chever et al. (2010) clearly showed that lateral advection of dissolved iron towards the Kerguelen plateau should be also considered as a predominant source of total dissolved iron (total apparent particulate iron and dissolved iron) above the plateau.

Thus, even if the "advection-scavenging model" applied to ${ }^{230} \mathrm{Th}$ and ${ }^{231} \mathrm{~Pa}$, cannot be strictly applied to other elements (like iron), it nevertheless shows that it is necessary to take this advection into account to establish the budget of other particle reactive elements, which have been treated in a one-dimensional way over the Kerguelen plateau (Blain et al., 2007).

\section{Conclusions}

In the wake of the Kerguelen plateau, ${ }^{231} \mathrm{~Pa}_{\mathrm{xs}}$ and ${ }^{230} \mathrm{Th}_{\mathrm{xs}}$ distributions in seawater and particles and their fractionation are in the range of those previously observed in the Southern Ocean. This study shows that in the Kerguelen wake dominated by biogenic silica, ${ }^{231} \mathrm{~Pa}$ removal is at least as efficient and possibly more efficient than ${ }^{230} \mathrm{Th}$ removal, thereby setting the $\mathrm{Pa} / \mathrm{Th}$ ratios and fractionation factor $\left(F_{\mathrm{Th} / \mathrm{Pa}} \leq 1\right)$ in the water column, and consequently in the sediments of this area of the Southern Ocean.

We confirm that along the eastern plateau escarpment, an intense scavenging occurs in the deep water as depicted by the decrease of both dissolved ${ }^{230} \mathrm{Th}_{\mathrm{xs}}$ and ${ }^{231} \mathrm{~Pa}_{\mathrm{xs}}$ concentrations. The lack of fractionation of ${ }^{231} \mathrm{~Pa}_{\mathrm{xs}}$ and ${ }^{230} \mathrm{Th}_{\mathrm{xs}}\left(F_{\mathrm{Th} / \mathrm{Pa}} \approx 1\right)$ associated with this intense scavenging was attributed to nepheloid layers inducing re-suspension of BSi-rich particles stripping the deep water column of both 
radionuclides. To our knowledge, this work is the first clear observation of boundary scavenging directly from the decrease of both dissolved ${ }^{231} \mathrm{~Pa}$ and ${ }^{230} \mathrm{Th}$ concentrations when a water mass flows along an "ocean boundary".

In addition, it sheds a new light on the boundary scavenging processes. Indeed, boundary scavenging, depicted in this study by changes in the fractionation of $\mathrm{Pa}$ and Th, occurs in the wake of Kerguelen due to the combination of both particle effect with a gradient in the particle fluxes (e.g. higher particle flux at the margin than in the open ocean) and the effect of particle composition (dominated here by opal).

On the Kerguelen plateau, using an "advection-scavenging model", we show that the advection of open-ocean water, rich in dissolved ${ }^{230} \mathrm{Th}$ and ${ }^{231} \mathrm{~Pa}$, plays a critical role in the radionuclides budget by balancing the drawdown of both nuclides concentrations due to the strong scavenging. Consequently, we strongly recommend that, so as to establish the distributions of other elements of interest in the water column in high scavenging areas (e.g. the Kerguelen plateau in this study), the advection of water from a lower scavenging area should be taken into account.

Ultimately, the future publications on Th and Pa distributions and their fractionation in contrasted areas of the ocean will provide more realistic representations of particle composition and particle dynamics, necessary to develop a more sophisticated modelling approach of the scavenging processes of particle-reactive elements in Global Circulation Models (Dutay et al., 2009).

Acknowledgements. We thank the captain and crew of the R/V Marion Dufresne, the PI of KEOPS project Stephane Blain and the chief scientist Bernard Quéguiner. We would like to thank Lionel Scouarnec and Christophe Guillerm (INSU) for their help with the in-situ pumps. We are grateful to Jean-Louis Reyss who enabled us to achieve the gamma measurements at LSM. We are especially thankful to Roger François and Walter Geibert for providing the Pa spikes allowing us to achieve this study. We thank Catherine Pradoux for her help in the clean laboratory. We are very grateful to the two anonymous reviewers for their critical and fruitful comments. This work was supported by the IPEV (Institut Paul Emile Victor), the INSU/CNRS and the LEGOS (Toulouse).

Edited by: S. W. A. Naqvi

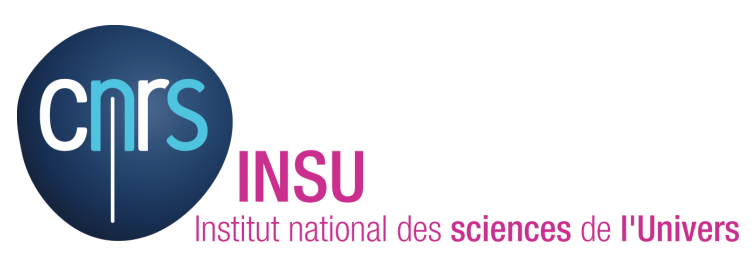

The publication of this article is financed by CNRS-INSU.

\section{References}

Anderson, R. F., Bacon, M. P., and Brewer, P. G.: Removal of ${ }^{230} \mathrm{Th}$ and ${ }^{231} \mathrm{~Pa}$ from open ocean, Earth Planet. Sc. Lett., 62, 7-23, 1983a.

Anderson, R. F., Bacon, M. P., and Brewer, P. G.: Removal of ${ }^{230} \mathrm{Th}$ and ${ }^{231} \mathrm{~Pa}$ at ocean margins, Earth Planet. Sc. Lett., 66, 73-90, $1983 b$.

Anderson, R. F., Lao, Y., Broecker, W. S., Trumbore, S. E., Hofmann, H. J., and Wolfi, W.: Boundary scavenging in the Pacific Ocean: a comparison of ${ }^{10} \mathrm{Be}$ and ${ }^{231} \mathrm{~Pa}$, Earth Planet. Sc. Lett., 96, 287-304, 1990.

Armand, L. K., Crosta, X., Quéguiner, B., Mosseri, J., and Garcia, N.: Late summer diatom biomass and community structure on and around the naturally iron-fertilised Kerguelen Plateau in the Southern Ocean, Deep-Sea Res. Pt. II, 55, 653-676, 2008.

Bacon, M. P.: Tracers of chemical scavenging in the ocean: boundary effects and large scale chemical fractionation, Philos. T. R. Soc. Lond., 325, 147-160, 1988.

Bacon, M. P. and Anderson, R. F.: Distribution of thorium isotopes between dissolved and particulate forms in the deep sea, J. Geophys. Res., 87, 2045-2056, 1982.

Bishop, J. K. B., Ketten, D. R., and Edmond, J. M.: The chemistry, biology and vertical flux of particulate matter from the upper 400 $m$ of the Cape Basin in the southeast Atlantic Ocean, Deep-Sea Res., 25, 1121-1161, 1978.

Blain, S., Quéguiner, B., Armand, L., Belviso, S., Bombled, B., Bopp, L., Bowie, A., Brunet, C., Brussaard, C., Carlotti, F., Christaki, U., Corbiére, A., Durand, I., Ebersbach, F., Fuda, J.-L., Garcia, N., Gerringa, L., Griffiths, B., Guigue, C., Guillerm, C., Jacquet, S., Jeandel, C., Laan, P., Lefévre, D., Lo Monaco, C., Malits, A., Mosseri, J., Obernosterer, I., Park, Y.-H., Picheral, M., Pondaven, P., Remenyi, T., Sandroni, V., Sarthou, G., Savoye, N., Scouarnec, L., Souhaut, M., Thuiller, D., Timmermans, K., Trull, T., Uitz, J., van Beek, P., Veldhuis, M., Vincent, D., Viollier, E., Vong, L., and Wagener, T.: Effect of natural iron fertilisation on carbon sequestration in the Southern Ocean, Nature, 446, 1070-1074, 2007.

Bradtmiller, L. I., Anderson, R. F., Fleisher, M. Q., and Burckle, L. H.: Diatom productivity in the equatorial Pacific Ocean from the last glacial period to the present: A test of the silicic acid leakage hypothesis, Paleoceanography, 21, PA4201, doi:10.1029/2006PA001282, 2006.

Bradtmiller, L. I., Anderson, R. F., Fleisher, M. Q., and Buckle, L. H.: Comparing glacial and Holocene opal fluxes in the Pacific sector of the Southern Ocean, Paleoceanography, 24, PA2214, doi:10.1029/2008PA001693, 2009.

Carlotti, F., Thibault-Botha, D., Nowaczyk, A., and Lefevre, D.: Zooplankton community structure, biomass and role in carbon fluxes during the second half of a phytoplankton bloom in the eastern sector of the Kerguelen Shelf (January-February 2005), Deep-Sea Res. Pt. II, 55, 720-733, 2008.

Chase, Z. and Anderson, R. F.: Comment on "On the importance of opal, carbonate, and lithogenic clays in scavenging and fractionating ${ }^{230} \mathrm{Th},{ }^{231} \mathrm{~Pa}$ and ${ }^{10} \mathrm{Be}$ in the ocean" by Luo, $\mathrm{S}$. and $\mathrm{Ku}, \mathrm{T}$. L., Earth Planet. Sc. Lett., 220, 213-222, 2004.

Chase, Z., Anderson, R. F., Fleisher, M. Q., Kubik, P. W.: The influence of particle composition and particle flux on scavenging of Th, Pa and Be in the ocean, Earth Planet. Sc. Lett., 204, 215229, 2002. 
Chase, Z., Anderson, R. F., Fleisher, M. Q., and Kubik, P. W.: Scavenging of ${ }^{230} \mathrm{Th},{ }^{231} \mathrm{~Pa}$ and ${ }^{10} \mathrm{Be}$ in the Southern Ocean $(\mathrm{SW}$ Pacific sector): The importance of particle flux, particle composition and advection, Deep-Sea Res. Pt. II, 50, 739-768, 2003.

Chever, F., Sarthou, G., Bucciarelli, E., Blain, S., and Bowie, A. R.: An iron budget during the natural iron fertilisation experiment KEOPS (Kerguelen Islands, Southern Ocean), Biogeosciences, 7, 455-468, doi:10.5194/bg-7-455-2010, 2010.

Choi, M. S., Francois, R., Sims, K., Bacon, M. P., Brown-Leger, S., Fleer, A. P., Ball, L., Schneider, D., and Pichat, S.: Rapid determination of ${ }^{230} \mathrm{Th}$ and ${ }^{231} \mathrm{~Pa}$ in seawater by desolvated micronebulization Inductively Coupled Plasma magnetic sector mass spectrometry, Mar. Chem., 76, 99-112, 2001.

Coppola, L., Roy-Barman, M., Mulsow, S., Povinec, P., and Jeandel, C.: Thorium isotopes as tracers of particles dynamics and deep water circulation in the Indian sector of the Southern Ocean (ANTARES IV), Mar. Chem., 100, 299-313, 2006.

Dutay, J.-C., Lacan, F., Roy-Barman, M., and Bopp, L.: Influence of particle size and type on ${ }^{231} \mathrm{~Pa}$ and ${ }^{230} \mathrm{Th}$ simulation with a global coupled biogeochemical-ocean general circulation model: A first approach, Geophysics, Geochemistry, Geosystems, 10, Q01011, doi:10.1029/2008GC002291, 2009.

Edmonds, H. N., Moran, S. B., Cheng, H., and Edwards, R. L.: ${ }^{230} \mathrm{Th}$ and ${ }^{231} \mathrm{~Pa}$ in the Arctic Ocean: implications for particle fluxes and basin-scale Th/Pa fractionation, Earth Planet. Sci. Lett., 227, 155-167, 2004.

Frew, R. D., Hutchins, D. A., Nodder, S., Sanudo-Wilhelmy, S., Tovar-Sanchez, A., Leblanc, K., Hare, C. E., and Boyd, P. W.: Particulate iron dynamics during FeCycle in subantarctic waters southeast of New Zealand, Global Biogeochem. Cy., 20, GB1S93, doi:10.1029/2005GB002558, 2006.

Fripiat, F., Cavagna, A.-J., Savoye, N., Dehairs, F., André, L., and Cardinal, D.: Isotopic constraints on the Si-biogeochemical cycle of the Antarctic Zone in the Kerguelen area (KEOPS), Mar. Chem., 123, 11-22, 2011.

Guo, L., Chen, M., and Gueguen, C.: Control of Pa/Th ratio by particulate chemical composition in the ocean, Geophys. Res. Lett., 29, 20, 1961-1963, 2002.

Hayes, C. T., Anderson, R. F., and Fleisher, M. Q.: Opal accumulation rates in the equatorial Pacific and mechanisms of deglaciation, Paleoceanography, 26, PA1207, doi:10.1029/2010PA002008, 2011.

Jacquet, S. H. M., Cardinal, D., Savoye, N., Obernosterer, I., Christaki, U., Monnin, C., and Dehairs, F.: Mesopelagic organic carbon remineralization in the Kerguelen Plateau region tracked by biogenic particulate Ba, Deep-Sea Res. Pt. II, 55, 868-879, 2008.

Jeandel, C., Venchiarutti, C., Bourquin, M., Pradoux, C., Lacan, F., van Beek, P., and Riotte, J.: Single Column Sequential Extraction of Ra, Nd, Th, Pa and U from a Natural Sample, Geostand. Geoanal. Res., doi:0.1111/j.1751-908X.2010.00087.x, 2011a.

Jeandel, C., Pradoux, C., Zhang, Y., van Beek, P., Lacan, F., Jones, M., and Pierce, C.: Land-to-ocean processes on and along the Kerguelen plateau traced by the REE concentrations and Nd isotopic composition, $43^{r d}$ International Liège Colloquium "Ocean Dynamics: Traces and Tracers", $2011 \mathrm{~b}$.

Leynaert, A., Tréguer, P., Lancelot, C., and Rodier, M.: Silicon limitation of biogenic silica production in the Equatorial Pacific, Deep-Sea Res. Pt. I, 48, 639-660, 2001.

Luo, S. and Ku, T.-L.: On the importance of opal, carbonate, and lithogenic clays in scavenging and fractionating ${ }^{230} \mathrm{Th},{ }^{231} \mathrm{~Pa}$ and ${ }^{10} \mathrm{Be}$ in the ocean, Earth Planet. Sci. Lett., 220, 201-211, 2004.

Marchal, O., François, R., Scholten, J.: Contribution of ${ }^{230}$ Th measurements to the estimation of the abyssal circulation, Deep-Sea Res. Pt. I, 54, 557-885, 2007.

Marinov, I., Gnanadesikan, A., Toggweiler, J. R., and Sarmiento, J. L.: The Southern Ocean biogeochemical divide, Nature, 441, 964-967, 2006.

McCartney, M. S. and Donohue, K. A.: A deep cyclonic gyre in the Australian-Antarctic Basin, Prog. Oceanogr., 75, 675-750, 2007.

Mongin, M., Molina, E., and Trull, T. W.: Seasonality and scale of the Kerguelen Plateau phytoplankton bloom: a remote sensing and modeling analysis of the influence of natural iron fertilization in the Southern Ocean, Deep-Sea Res. Pt. II, 55, 880-892, 2008.

Moran, S. B., Charette, M. A., and Hoff, J. A.: Distribution of ${ }^{230} \mathrm{Th}$ in the Labrador Sea and its relation to ventilation, Earth Planet. Sc. Lett., 150, 151-160, 1997.

Moran, S. B., Shen, C.-C., Edmonds, H. N., Weinstein, S. E., Smith, J. N., Edwards, R. L.: Dissolved and particulate ${ }^{231} \mathrm{~Pa}$ and ${ }^{230} \mathrm{Th}$ in the Atlantic Ocean: constraints on intermediate/deep water age, boundary scavenging and ${ }^{231} \mathrm{~Pa} /{ }^{230} \mathrm{Th}$ fractionation, Earth Planet. Sc. Lett., 203, 999-1014, 2002.

Moran, S. B., Shen, C.-C., Edwards, R. L., Edmonds, H. N., Scholten, J. C., Smith, J. N., and Ku, T.-L.: ${ }^{231} \mathrm{~Pa}$ and ${ }^{230} \mathrm{Th}$ in surface sediments of Arctic Ocean: implications for ${ }^{231} \mathrm{~Pa} /{ }^{230} \mathrm{Th}$ fractionation, boundary scavenging, and advective export, Earth Planet. Sc. Lett., 234, 235-248, 2005.

Mosseri, J., Quéguiner, B., Armand, L., and Cornet-Barthaux, V.: Impact of iron on silicon utilization by diatoms in the Southern Ocean: a case study of the $\mathrm{Si} / \mathrm{N}$ cycle decoupling in a naturally iron-enriched area, Deep-Sea Res. Pt. II, 55, 801-819, 2008.

Nozaki, Y. and Horibe, Y.: The water column distributions of thorium isotopes in the western North Pacific, Earth Planet. Sc. Lett., 54, 203-216, 1981.

Nozaki, Y. and Nakanishi, T.: ${ }^{231}$ Paand ${ }^{230}$ Th profiles in the open ocean water column, Deep-Sea Res., 32, 1209-1220, 1985.

Nozaki, Y., Zhang, J., and Takeda, A.: ${ }^{210} \mathrm{~Pb}$ and ${ }^{210} \mathrm{Po}$ in the equatorial Pacific and the Bering Sea: the effects of biological productivity and boundary scavenging, Deep-Sea Res. Pt. II, 44, 2203-2220, 1997.

Obernosterer, I., Christaki, U., Lefèvre, D., Catala, P., Van Wambeke, F., and Lebaron, P.: Rapid bacterial mineralization of organic carbon produced during a phytoplankton bloom induced by natural iron fertilization in the Southern Ocean, DeepSea Res. Pt. II, 55, 777-789, 2008.

Okubo, A., Obata, H., Gamo, T., Minami, H., and Yamada, M.: Scavenging of ${ }^{230}$ Th in the Sulu Sea, Deep-Sea Res. Pt. II, 54, 50-59, 2007.

Park, Y.-H., Roquet, F., Fuda, J. L., and Durand, I.: Circulation over and around the Kerguelen Plateau, Deep-Sea Res. Pt. II, 55, 566-581, 2008.

Pichat, S.: Variations du rapport $\left({ }^{231} \mathrm{~Pa} /{ }^{230} \mathrm{Th}\right)_{x s, 0}$ et de la composition isotopique du zinc dans des sédiments de l'océan Pacifique équatorial au Quaternaire. Implications pour la productivité biologique et relations avec la thermocline, Ph.D. thesis, Ecole Normale Supérieure de Lyon, Laboratoire des Sciences de la Terre, 2001. 
Pichat, S., Sims, K. W. W., François, R., McManus, J. F., Brown-Leger, S., and Albarède, F.: Lower export production during glacial periods in the equatorial Pacific derived from $\left({ }^{231} \mathrm{~Pa} /{ }^{230} \mathrm{Th}\right)_{x s, 0}$ measurements in deep-sea sediments, Paleoceanography, 19, PA4023, doi:10.1029/2003PA000994, 2004.

Pollard, R. T., Salter, I., Sanders, R. J., Lucas, M. I., Moore, M. C., Mills, R. A., Statham, P. J., Allen, J. T., Baker, A. R., Bakker, D. C. E., Charette, M. A., Fielding, S., Fones, G. R., French, M., Hickman, A. E., Holland, R. J., Hughes, J. A., Jickells, T. D., Lampitt, R. S., Morris, P. J., Nédélec, F. H., Nielsdóttir, M., Planquette, H., Popova, E. E., Poulton, A. J., Read, J. F., Seeyave, S., Smith, T., Stinchcombe, M., Taylor, S., Thomalla, S., Venables, H. J., Williamson, R., and Zubkov, M. V.: Southern Ocean deep-water carbon export enhanced by natural iron fertilization, Nature, 457, 577-580, 2009.

Regelous, M., Turner, S. P., Elliott, T. R., Rostami, K., and Hawkesworth, C. J.: Measurements of femtogram quantities of protactinium in silicate rock samples by multicollector inductively coupled plasma mass spectrometry, Analytical Chemistry, 54, 1142-1147, 2004.

Roquet, F., Park, Y.-H., Guinet, C., Bailleul, F., and Charrassin, J.B.: Observations of the Fawn Trough Current over the Kerguelen Plateau from instrumented elephant seals, J. Marine Syst., 78, 377-393, 2009.

Roy-Barman, M.: Modelling the effect of boundary scavenging on Thorium and Protactinium profiles in the ocean, Biogeosciences, 6, 3091-3107, doi:10.5194/bg-6-3091-2009, 2009.

Roy-Barman, M., Chen, J. H., and Wasserburg, G. J.: ${ }^{230} \mathrm{Th}^{232} \mathrm{Th}$ systematics in the central Pacific Ocean: The sources and the fates of Thorium, Earth Planet. Sc. Lett., 139, 351-363, 1996.

Roy-Barman, M., Coppola, L., and Souhaut, M.: Thorium isotopes in the Western Mediterranean Sea: insight into the marine particle dynamics, Earth Planet. Sc. Lett., 196, 161-174, 2002.

Roy-Barman, M., Jeandel, C., Souhaut, M., Rutgers van der Loeff, M. M., Voege, I., Leblond, N., and Freydier, R.: The influence of particle composition on thorium scavenging in the NE Atlantic Ocean (POMME experiment), Earth Planet. Sc. Lett., 240, 681693, 2005.

Rutgers van der Loeff, M. M. and Berger, G. W.: Scavenging of ${ }^{230}$ Th and ${ }^{231} \mathrm{~Pa}$ near the Antarctic Polar Front in the South Atlantic, Deep-Sea Res. Pt. I, 40, 339-357, 1993.

Rutgers van der Loeff, M. M. and Moore, W. S.: Determination of natural radioactive tracers, Methods of Seawater Analysis, Chapter 13, 3 Edn., Verlag Chemie, Weinheim, 365-397, 1999.

Sarmiento, J. L., Hughes, T. M. C., Stouffer, R. J., and Manabe, S.: Simulated response of the ocean carbon cycle to anthropogenic climate warming, Nature, 393, 245-249, 1998.

Savoye, N., Trull, T. W., Jacquet, S. H. M., Navez, J., and Dehairs, F.: ${ }^{234}$ Th-based export fluxes during a natural iron fertilization experiment in the Southern Ocean (KEOPS), Deep-Sea Res. Pt. II, 55, 841-855, 2008.

Scholten, J. C., Rutgers van der Loeff, M. M., and Michel, A.: Distribution of ${ }^{230} \mathrm{Th}$ and ${ }^{231} \mathrm{~Pa}$ in the water column in relation to the ventilation of the deep Arctic basins, Deep-Sea Res. Pt. II, 42, 1519-1531, 1995.

Scholten, J. C., Fietzke, J., Mangini, A., Stoffers, P., Rixen, T., Gaye-Haake, B., Blanz, T., Ramaswamy, V., Sirocko, F., Schulz, H., and Ittekkot, V.: Radionuclide fluxes in the Arabian Sea: the role of particle composition, Earth Planet. Sc. Lett., 230, 319-
337, 2005.

Scholten, J. C., Fietzke, J., Mangini, A., Garbe-Schönberg, C.-D., Eisenhauer, A., Schneider, R., and Stoffers, P.: Advection and scavenging: Effects on ${ }^{230} \mathrm{Th}$ and ${ }^{231} \mathrm{~Pa}$ distribution off Southwest Africa, Earth Planet. Sc. Lett., 271, 159-169, 2008.

Spencer, D. W., Bacon, M. P., and Brewer, P. G.: Models of the distribution of ${ }^{210} \mathrm{~Pb}$ in a section across the north equatorial Atlantic Ocean, J. Mar. Res., 39, 119-138, 1981.

Tachikawa, K.: Apport de concentrations de Terres Rares et des compositions isotopiques de Néodyme à l'étude de processus dans la colonne d'eau : cas de l'Atlantique Tropical Nord-Est (sites EUMELI), Ph.D. thesis, Université Toulouse III, France, 1997.

Thomas, A. L., Henderson, G. M., and Robinson, L. F.: Interpretation of the ${ }^{231} \mathrm{~Pa} /{ }^{230} \mathrm{Th}$ paleocirculation proxy: New watercolumn measurements from the southwest Indian Ocean, Earth Planet. Sc. Lett., 241, 493-504, 2006.

Tréguer, P. and Pondaven, P.: Climatic changes and the carbon cycle in the Southern Ocean: a step forward, Deep-Sea Res. Pt. II, 49, 1597-1600, 2002.

Turnewitsch, R., Reyss, J.-L., Nycander, J., Waniek, J. J., and Lampitt, R. S.: Internal tides and sediment dynamics in the deep sea - Evidence from radioactive ${ }^{234} \mathrm{Th} /{ }^{238} \mathrm{U}$ disequilibria, DeepSea Res. Pt. I, 55, 1727-1747, 2008.

van Beek, P., Bourquin, M., Reyss, J.-L., Souhaut, M., Charrette, M. A, and Jeandel, C.: Radium isotopes to investigate the water mass pathways on the Kerguelen Plateau (Southern Ocean), Deep-Sea Res. Pt. II, 55, 622-637, 2008.

Venchiarutti, C., Jeandel, C., and Roy-Barman, M.: Particle dynamics study in the wake of Kerguelen Island using thorium isotopes, Deep-Sea Res. Pt. I, 55, 1343-1363, 2008.

Vogler, S., Scholten, J., Rutgers van der Loeff, M. M., and Mangini, A.: ${ }^{230} \mathrm{Th}$ in the Eastern North Atlantic: the importance of water mass ventilation in the balance of ${ }^{230} \mathrm{Th}$, Earth Planet. Sc. Lett., 156, 61-74, 1998.

Walter, H. J., Rutgers van der Loeff, M. M., and Hoeltzen, H.: Enhanced scavenging of ${ }^{231} \mathrm{~Pa}$ relative to ${ }^{230} \mathrm{Th}$ in the South Atlantic south of the Polar Front: Implications for the use of the ${ }^{231} \mathrm{~Pa} /{ }^{230} \mathrm{Th}$ ratio as a paleoproductivity proxy, Earth Planet. Sc. Lett., 149, 85-100, 1997.

Walter, H. J., Rutgers van der Loeff, M. M., and Francois, R.: Reliability of the ${ }^{231} \mathrm{~Pa} /{ }^{230} \mathrm{Th}$ activity ratio as a tracer for bioproductivity of the ocean, in: Use of Proxies in Paleoceanography: Examples from the South Atlantic, edited by: Fischer, G. and Wefer, G., Springer-Verlag, Berlin, 393-408, 1999.

Walter, H. J., Geibert, W., Rutgers van der Loeff, M. M., Fischer, G., and Bathmann, U.: Shallow vs deep-water scavenging of ${ }^{231} \mathrm{~Pa}$ and ${ }^{230} \mathrm{Th}$ in radionuclide enriched waters of Atlantic sector of Southern Ocean, Deep-Sea Res. Pt. I, 48, 471-493, 2001.

Yu, E.-F., Francois, R., Bacon, M. P., Honjo, S., Fleer, A. P., Manganini, S. J., Rutgers van der Loeff, M. M., and Ittekot, V.: Trapping efficiency of bottom-tethered sediment traps estimated from intercepted fluxes of ${ }^{230} \mathrm{Th}$ and ${ }^{231} \mathrm{~Pa}$, Deep-Sea Res. Pt. I, 48, 865-889, 2001.

Zhang, Y., Lacan, F., and Jeandel, C.: Dissolved rare earth elements tracing lithogenic inputs over the Kerguelen Plateau (Southern Ocean), Deep-Sea Res. Pt. II, 55, 638-652, 2008. 